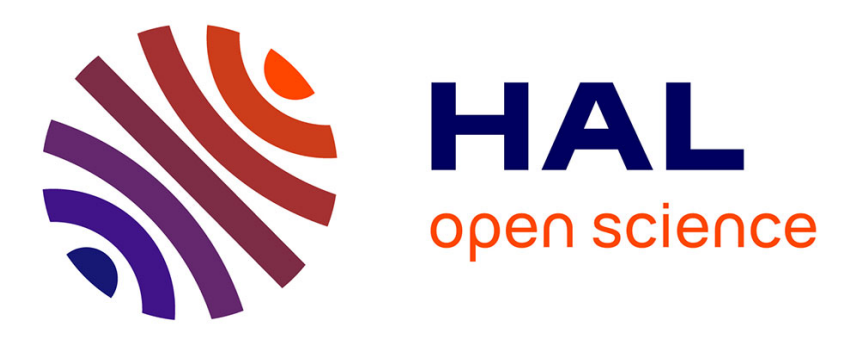

\title{
Living (stained) deep-sea foraminifera from the Sea of Marmara: A preliminary study
}

\author{
Christophe Fontanier, Delphine Dissard, Livio Ruffine, Briony Mamo, \\ Emmanuel Ponzevera, E. Pelleter, François Baudin, Angélique Roubi, \\ Sandrine Chéron, Audrey Boissier, et al.
}

\section{To cite this version:}

Christophe Fontanier, Delphine Dissard, Livio Ruffine, Briony Mamo, Emmanuel Ponzevera, et al.. Living (stained) deep-sea foraminifera from the Sea of Marmara: A preliminary study. Deep Sea Research Part II: Topical Studies in Oceanography, 2018, 153, pp.61-78. 10.1016/j.dsr2.2017.12.011 . hal-01958195

\section{HAL Id: hal-01958195 \\ https://hal.sorbonne-universite.fr/hal-01958195}

Submitted on 17 Dec 2018

HAL is a multi-disciplinary open access archive for the deposit and dissemination of scientific research documents, whether they are published or not. The documents may come from teaching and research institutions in France or abroad, or from public or private research centers.
L'archive ouverte pluridisciplinaire HAL, est destinée au dépôt et à la diffusion de documents scientifiques de niveau recherche, publiés ou non, émanant des établissements d'enseignement et de recherche français ou étrangers, des laboratoires publics ou privés. 


\title{
Living (stained) deep-sea foraminifera from the Sea of Marmara: A preliminary study
}

\author{
C. Fontanier ${ }^{\mathrm{a}, \mathrm{b}, \mathrm{c}, \mathrm{d}, *}$, D. Dissard ${ }^{\mathrm{e}}$, L. Ruffine ${ }^{\mathrm{f}}$, B. Mamo $^{\mathrm{g}}$, E. Ponzevera ${ }^{\mathrm{f}}$, E. Pelleter ${ }^{\mathrm{f}}, \mathrm{F}$. Baudin $^{\mathrm{h}}$, \\ A. Roubi ${ }^{\mathrm{c}}$, S. Chéron ${ }^{\mathrm{f}}$, A. Boissier ${ }^{\mathrm{f}}$, N. Gayet ${ }^{\mathrm{i}}, \mathrm{S}$. Bermell-Fleury ${ }^{\mathrm{j}}$, M. Pitel $^{\mathrm{j}}$, V. Guyader $^{\mathrm{f}}$, \\ F. Lesongeurk ${ }^{\mathrm{k}}$, F. Savignac ${ }^{\mathrm{h}}$ \\ a Université de Bordeaux, CNRS, Environnements et Paléo-environnements Océaniques et Continentaux, UMR 5805, F-33600 Pessac, France \\ ${ }^{\mathrm{b}}$ FORAM, Foraminiferal Study Group, F-49140 Villevêque, France \\ ${ }^{\mathrm{c}}$ Ifremer, Laboratoire Géodynamique et Enregistrement Sédimentaire, Centre de Brest, Technopôle de Brest-Iroise, BP 70, F-29280 Plouzané, France \\ ${ }^{\mathrm{d}}$ Univ. Angers, F-49035 Angers, France \\ e IRD-Sorbonne Universités, UPMC, Univ Paris 06-CNRS-MNHN, LOCEAN Laboratory 4 place Jussieu, F-75252 Paris cedex 05, France \\ ${ }^{\mathrm{f}}$ Ifremer, Laboratoire de Géochimie et de Métallogénie, Centre de Brest, Technopôle de Brest-Iroise, BP 70, F-29280 Plouzané, France \\ ${ }^{\mathrm{T}}$ The University of Hong Kong, Department of Biological Sciences, Pokfulam Road, Hong Kong SAR, China \\ ${ }^{\text {h }}$ Sorbonne Universités, UPMC, Univ Paris 06, UMR 7193 ISTeP, Institut des Sciences de la Terre de Paris, Equipe Evolution et Modélisation des Bassins Sédimentaires, F- \\ 75252 Paris Cedex 05, France

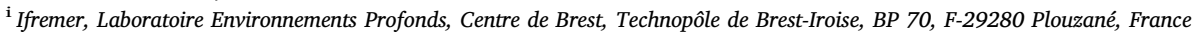 \\ ${ }^{\mathbf{j}}$ Ifremer, Service Cartographie, Traitement de Données et Instrumentation, Centre de Brest, Technopôle de Brest-Iroise, BP 70, F-29280 Plouzané, France \\ ${ }^{\mathbf{k}}$ Ifremer, Laboratoire de Microbiologie des Environnements Extrêmes, Centre de Brest, Technopôle de Brest-Iroise, BP 70, F-29280 Plouzané, France
}

\begin{abstract}
A B S T R A C T
In this preliminary study, we investigate living (stained) foraminifera from the Sea of Marmara. We focus on the faunal composition and geochemical signatures (trace elements, carbon and oxygen stable isotopes) in foraminiferal tests at two deep-sea sites (329 and $\sim 1240 \mathrm{~m}$ depth respectively). Documented by ROV observations and sampling, both study areas are heterogeneous (including bacterial mats and carbonate concretions), proximal to cold seeps and consist of dysoxic bottom water $\left(\mathrm{O}_{2}<20 \mu \mathrm{mol} / \mathrm{L}\right)$. The prevailing dysoxia at both study areas restricts foraminiferal diversity to very low values $\left(\mathrm{S}<9, \mathrm{H}^{\prime}<0.97\right)$. Stress-tolerant species Bolivina vadescens and Globobulimina affinis dominate living faunas at both sites. The highest foraminiferal standing stock is recorded at the shallowest site underneath a spreading bacterial mat. No benthic foraminifera from either site possess geochemical signatures of methane seepage. Our biogeochemical results show that use of foraminiferal $\mathrm{Mn} / \mathrm{Ca}$ ratios as a proxy for bottom water oxygenation depends strongly on regional physiography, sedimentary processes and water column structure.
\end{abstract}

\section{Introduction}

Hydrocarbon seeps represent benthic environments of major interest to scientists regarding biogeochemical functioning and fluid generation/migration along continental margins, and deep-sea biodiversity in extreme ecosystems (e.g., Boetius and Wenzhöfer, 2013). Research into these unique ecosystems is additionally of interest to mining industries seeking to exploit the rich gas reserves of hydrocarbon seeps (Sills and Wheeler, 1992; Fleischer et al., 2001; Prinzhofer and Deville, 2013). Most seeps are characterized by methane and hydrogen sulfide (e.g., Borowski et al., 1999; Campbell, 2006) forming a brine which sustains chemosynthetic communities of endemic metazoa (e.g., vesicomyid, mytilid or siboglinid) and mutually endosymbiotic prokaryotes (mainly sulfide-oxidizing bacteria) (e.g., Sibuet and Olu, 1998; Boetius et al., 2000; Sahling et al., 2002; Levin and Mendoza, 2007). Variation in sulfide and methane fluxes within the uppermost sediments generate a distinct biozonation of chemoautotrophic prokaryotes and a patchy distribution of benthic eukaryotes (e.g., Sibuet and Olu, 1998; Sahling et al., 2002; Foucher et al., 2009).

Living benthic Foraminifera (Eukaryota, Rhizaria) from modern cold seeps have been investigated over the last two decades (Akimoto et al., 1994; Sen Gupta and Aharon, 1994; Kitazato, 1996; Sen Gupta et al., 1997, 2007; Rathburn et al., 2000, 2003; Bernhard et al., 2001;

\footnotetext{
* Corresponding author at: Université de Bordeaux, CNRS, Environnements et Paléo-environnements Océaniques et Continentaux,Continentaux, UMR 5805, F-33600 Pessac, France. E-mail address: c.fontanier@foram.eu.com (C. Fontanier).
} 
Torres et al., 2003; Hill et al., 2004; Heinz et al., 2005; Panieri, 2006; Mackensen et al., 2006; Lobegeier and Sen Gupta, 2008; Fontanier et al., 2014a; Herguera et al., 2014; Wollenburg et al., 2015). Foraminiferal species living in cold seep ecosystems are not endemic/ exotic but are recruited from adjacent non-seep zones (e.g., Sen Gupta and Aharon, 1994; Kitazato, 1996; Sen Gupta et al., 1997; Rathburn et al., 2000, 2003; Lobegeier and Sen Gupta, 2008; Fontanier et al., 2014a; Herguera et al., 2014). A wide array of metabolic adaptations (facultative anaerobic metabolism, mutualism with prokaryotes), habitat and food preference (elevated epibiotic habitat, bacteriovore) explain foraminiferal occurrence in methane- and sulfide-enriched sediments (e.g., Bernhard et al., 2001; Panieri, 2006; Mackensen et al., 2006; Sen Gupta et al., 2007; Lobegeier and Sen Gupta, 2008). The $\delta^{13} \mathrm{C}$ values in (living) foraminiferal tests record the seepage of methane-enriched fluid, with a clear shift (several per mil units) to lower signatures compared to adjacent non-seep areas (Sen Gupta and Aharon, 1994; Rathburn et al., 2000, 2003; Hill et al., 2004; Mackensen et al., 2006; Fontanier et al., 2014a; Wollenburg et al., 2015). The lack of major $\delta^{13} \mathrm{C}$ isotopic variability recorded in living foraminiferal tests from methane-rich seep zones vs. hydrate-gas fluids, leads to the assumption that foraminifera mostly calcify during periods of low methane discharge or during intermittent episodes of seawater injection into the sediment (Torres et al., 2003; Panieri, 2006; Fontanier et al., 2014a). Furthermore, ${ }^{13} \mathrm{C}$-depleted food sources (e.g., methanotroph bacterial biomass) and/or prokaryotic symbionts may contribute to the observed carbon isotope depletion in foraminiferal shells (Sen Gupta and Aharon, 1994; Rathburn et al., 2003; Hill et al., 2004; Panieri, 2006; Mackensen et al., 2006). Panieri (2006) has documented lighter protoplasmic $\delta^{13} \mathrm{C}(-21.4 \%)$ for foraminifera living in hydrocarbon seeps compared to a non-seep adjacent area, suggesting that bacterial mats like Beggiatoa (prokaryotes) (with $\delta^{13} \mathrm{C}$ comprised between to -25.5 and $-21.5 \%$ ) are a foraminiferal food source. The concentration of trace elements within foraminiferal tests is considered a reliable proxy for a wide array of environmental parameters (e.g., temperature, carbonate chemistry, organic matter flux) (e.g. Nurnberg et al., 1996; Lea, 1999; Dissard et al., 2010a, b; Munsel et al., 2010). Therefore trace-metal composition within foraminiferal tests may be considered a relevant proxy for methane seepages and sulfate reduction.

In this study, we investigate living (stained) foraminifera from the Sea of Marmara. We focus on faunal composition and geochemical signatures (trace elements, carbon and oxygen stable isotopes) in foraminiferal tests from two deep-sea sites sampled with the ROV "Victor 6000' (MARSITE Cruise aboard the RV "Pourquoi Pas?", November 2014) (Fig. 1, Table 1). Both study areas, located in the Central High and the south Çinarcik Basin (at 329 and $\sim 1240 \mathrm{~m}$ depth respectively), are entrenched by dysoxic bottom waters $\left(\mathrm{O}_{2}<20 \mu \mathrm{mol} / \mathrm{L}\right.$ ) (Fig. 2; Table 1). Very high-resolution bathymetry, geophysical, geological and geochemical data have revealed that the Sea of Marmara is characterized by hydrocarbon seeps where methane is overwhelmingly present, but have differing origins (e.g., Çağatay et al., 2004; Halbach et al.,; Géli et al., 2008; Zitter et al., 2008; Bourry et al., 2009; Chevalier et al., 2011; Crémière et al., 2012). The Central High is characterized by fluid emissions enriched in thermogenic methane whereas the south Çinarcik Basin is preferentially supplied with biogenic (microbial-derived) gas (Bourry et al., 2009). The objectives of our study are: (1) to compare the living benthic communities (Foraminifera, Prokaryota) between both stations and (2), to investigate the putative geochemical imprint of seeps environments in living foraminiferal tests through trace element (i.e., $\mathrm{Mn} / \mathrm{Ca}, \mathrm{Mg} / \mathrm{Ca}, \mathrm{Sr} / \mathrm{Ca}, \mathrm{Ba} / \mathrm{Ca})$ and stable isotopes $\left(\delta^{13} \mathrm{C}, \delta^{18} \mathrm{O}\right)$ analyses.

\section{Study area}

The Sea of Marmara is a highly-faulted sedimentary basin located within Turkish territory between the Mediterranean and Black Seas
(Fig. 1). The boundary between the Anatolian plate and the Eurasian plate, the North Anatolian Fault (NAF), crosses the Sea of Marmara in an approximately east-west direction. Composed of different segments, it has generated several major earthquakes during the twentieth century; the most recent one being the $\mathrm{Mw}=7.4$ Izmit earthquake in August 1999 (Karabulut et al., 2002; Kuşçu et al., 2005; Carton et al., 2007; Gasperini et al., 2011) (Fig. 1). The Sea of Marmara is characterized by three main basins which from east to west are called the Çinarcik Basin, the Central Basin and the Tekirdağ Basin. These basins are about $1250 \mathrm{~m}$ deep and separated from each other by bathymetric highs. The Central and Western Highs (Fig. 1) have been described as transpressional structures resulting from the overall strain of the NAF (Okay et al., 1999).

Two distinct layers can be observed in the Sea of Marmara water column (e.g., Beşiktepe et al., 1994). The southward Bosphorus jet, flowing from the Black Sea into the Sea of Marmara mainly drives the upper layer (20-30 m thick) with brackish waters (Alavi, 1988) and seasonal surface temperatures of $3-25^{\circ} \mathrm{C}$. Denser Mediterranean waters enter the Sea of Marmara from the Aegean Sea through the Dardanelles Strait as a turbulent, buoyant plume and form the subhalocline basin waters (Beşiktepe et al., 1994). In the Çinarcik Basin, this water mass, characterized by high and relatively homogeneous salinity $(=38.7$ psu), constant temperature $\left(\sim 14.4^{\circ} \mathrm{C}\right)$ and low oxygen $(<20 \mu \mathrm{mol} / \mathrm{L})$, remains relatively stagnant over long periods of time, while the Tekirdağ Basin's waters are frequently renewed (Alavi, 1988) (Fig. 2). This generates more pronounced minimum salinity and oxygen conditions in the bottom waters of the Çinarcik Basin (Fig. 2) (Alavi, 1988). The primary productivity in the Sea of Marmara is about $70 \mathrm{~g} \mathrm{C} / \mathrm{m}^{2} / \mathrm{yr}$ (Ünlüata and Özsoy, 1986) triggered by Black Sea surface-water nutrients, vertical mixing and local photic zone recycling (Bastürk et al., 1986).

To our knowledge, there are no publications regarding the living deep-sea foraminifera from the Sea of Marmara. To date, only a few studies have dealt with dead/fossil foraminifera from the deep basins (Alavi, 1988; Çağatay et al., 2000; Kaminski et al., 2002; Kirci-Elmas et al., 2008). Alavi (1988) examined fossil foraminiferal assemblages in two long sediment cores collected in the Çinarcik Basin at a depth of $1200 \mathrm{~m}$. Both archives were characterized by moderate to high organic carbon content (1.0-1.8\% dry weight). Fossil faunas were typical of oxygen-depleted and organic matter-enriched environments. They were dominated by Melonis pompilioides, Chilostomella mediterranensis, Brizalina alata, Brizalina spathulata and Bulimina inflata. Çağatay et al. (2000), reported the timing of Late Glacial-Holocene connections between the Mediterranean and Black Seas where two Holocene Sea of Marmara basin archives (370 and $700 \mathrm{~m}$ depths) yielded deep-sea fossil foraminifera. Organic matter-enriched intervals (i.e., sapropelic layers), which documented the establishment of water-column stratification and water column hypoxia (10,600 years BP), were characterized by Buliminids (Bulimina aculeatea, B. inflata), Bolivinids (B. spathulata, B. dilatata, B. alata), Cassidulina crassa and Hyalinea balthica (Çă̆atay et al., 2000). Kaminski et al. (2002) studied Holocene foraminiferal assemblages in four gravity cores gathered between 64 and $549 \mathrm{~m}$ and also focused on marine connections between the Marmara, Aegean and Black Seas. At the deepest station located in the western Sea of Marmara, they recorded the dominance of Fursenkoina with Brizalina and Bulimina at the base of the sapropelic layers (Kaminski et al., 2002). Sapropel layers themselves were barren of foraminifera, or contained few individuals of Chilostomella, Bolivina, Brizalina and Globobulimina. Kirci-Elmas et al. (2008) described fossil foraminifera from two Holocene records gathered in the Central Basin $(\sim 700$ and $\sim 900 \mathrm{~m}$ depth). Buliminids (B. marginata, B. costata), Bolivinids (B. alata, B. dilatata, B. striatula), H. balthica and Chilostomella ovoidea dominated sapropelic and post-sapropelic sediments. 

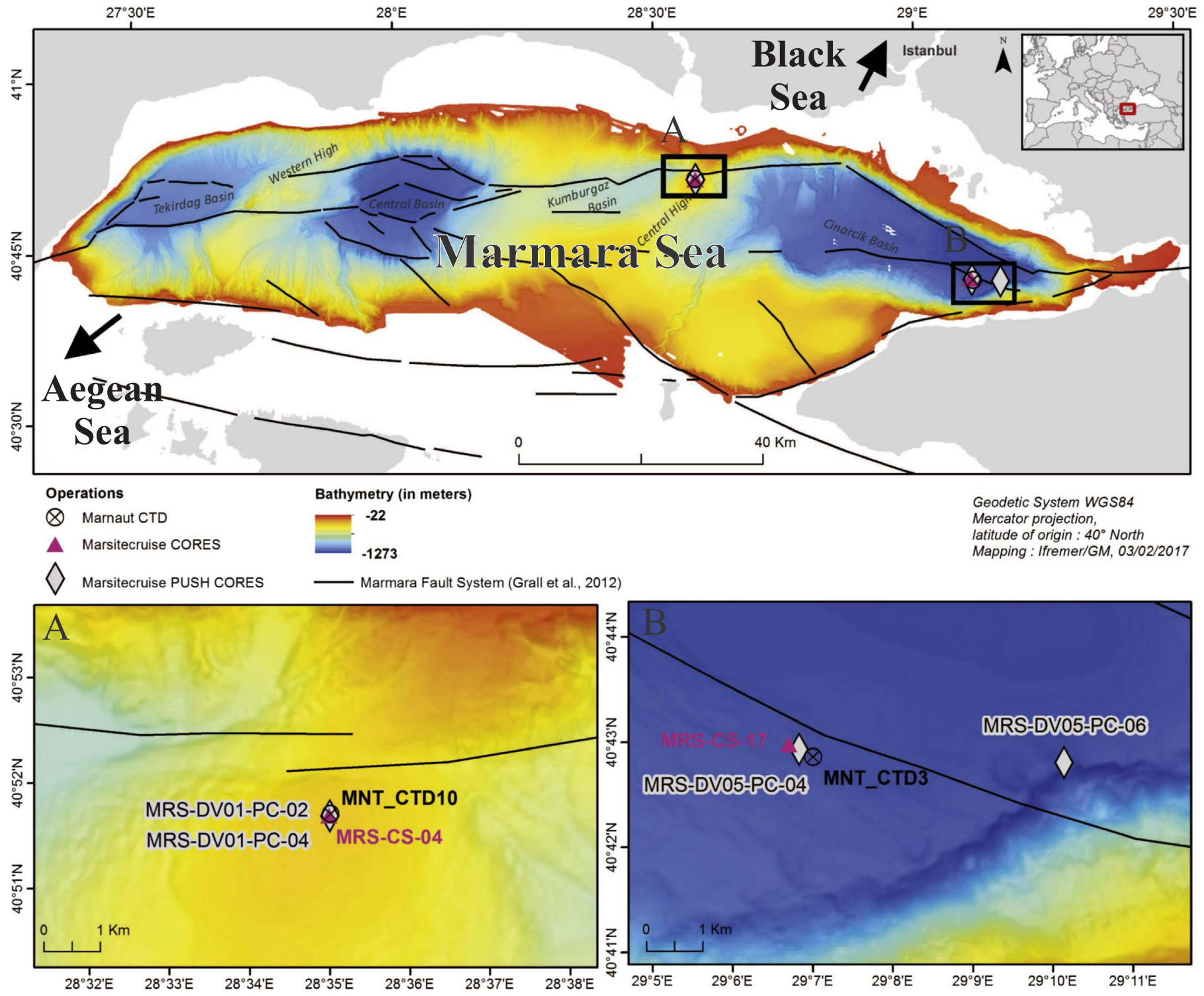

Fig. 1. Location of push cores (MRS-DV01-PC-02, MRS-DV01-PC-04, MRS-DV05-PC-04 and MRS-DV05-PC-06) and Calypso cores (MRS-CS-04 and MRS-CS-1) retrieved from the Sea of Marmara. Related geographic coordinates, depths and environmental parameters are listed in Tables 1 and 2. Black stars correspond to CTD casts (MNT_CTD3 and MNT_CTD10), taken during the MARNAUT cruise (2007) (data available online at http://www.ifremer.fr/sismer/index_FR.htm).

Table 1

Coordinates and sampling depth of all push cores investigated in this paper. Push cores were gathered with the ROV 'Victor 6000' during the MARSITE cruise (November 2014). Physicochemical parameters including BWT (bottom-water temperature), BWS (bottom-water salinity) and BWO (bottom-water oxygenation) were extrapolated from two CTD casts achieved during the MARNAUT cruise ${ }^{*}$ ) (data available at http://www.ifremer.fr/sismer/index FR.htm). Bottom-water oxygen (BWO), Oxygen saturation, bottom-water oxygen at saturation $\left(\mathrm{BWO}_{\text {sat }}\right.$ ) and apparent oxygen utilization (AOU) were calculated using http://ocean.ices.dk/Tools/Calculator.aspx. The $\delta^{13} \mathrm{C}$ of dissolved inorganic carbon in bottom water $\left(\delta^{13} \mathrm{C}_{\mathrm{DIC}}\right)$ was calculated using Kroopnick's equation (Kroopnick, 1985). The $\delta^{18} \mathrm{O}$ of bottom water $\left(\delta^{18} \mathrm{O}_{\mathrm{BW}}\right)$ is described in Rank et al. (1999). The $\delta^{13} \mathrm{C}$ of authigenic carbonate collected at both study sites $\left(\delta^{13} \mathrm{C}_{-} \mathrm{CaCO}_{3}\right)$ is presented in Chevalier et al. (2011). The $\delta^{18} \mathrm{O}$ of equilibrium calcite $\left(\delta^{18} \mathrm{O}_{\text {e.c. }}\right.$ ) was calculated by following equations by O'Neil et al. (1969) and Friedman and O'Neil (1977). The $\delta^{13} \mathrm{C}$ of methane characterizing active seeps on both study areas is described in Bourry et al. (2009).

\begin{tabular}{|c|c|c|c|c|c|c|c|c|c|c|}
\hline Push-core reference & $\begin{array}{l}\text { Interval } \\
(\mathrm{cm})\end{array}$ & $\begin{array}{l}\mathrm{S} 1 \\
(\mathrm{mg} / \mathrm{g})\end{array}$ & $\begin{array}{l}\mathrm{S} 2 \\
(\mathrm{mg} / \mathrm{g})\end{array}$ & $\begin{array}{l}\text { Tmax } \\
\left({ }^{\circ} \mathrm{C}\right)\end{array}$ & $\begin{array}{l}\mathrm{S} 3 \\
(\mathrm{mg} / \mathrm{g})\end{array}$ & $\begin{array}{l}\text { TOC } \\
\text { (\%) }\end{array}$ & $\begin{array}{l}\mathrm{HI} \\
(\mathrm{mg} \mathrm{HC} / \mathrm{g} \text { TOC) }\end{array}$ & $\begin{array}{l}\text { OI } \\
\text { mg CO2/g TOC }\end{array}$ & $\begin{array}{l}\operatorname{MinC} \\
(\%)\end{array}$ & $\begin{array}{l}\text { eq } \mathrm{CaCO} 3 \\
(\%)\end{array}$ \\
\hline \multirow[t]{4}{*}{ MRS-DV01-PC-02 } & $0-2$ & 0.04 & 5.05 & 424 & 3.25 & 2.35 & 215 & 138 & 2.17 & 18 \\
\hline & $1-2$ & 0.04 & 2.86 & 421 & 2.27 & 1.77 & 162 & 128 & 2.19 & 18 \\
\hline & $4-6$ & 0.05 & 2.39 & 416 & 2.59 & 1.51 & 158 & 172 & 2.24 & 19 \\
\hline & $6-8$ & 0.08 & 1.99 & 411 & 1.92 & 1.43 & 140 & 135 & 2.24 & 19 \\
\hline \multirow[t]{2}{*}{ MRS-DV05-PC-04 } & $0-1$ & 0.08 & 6.75 & 406 & 5.05 & 2.86 & 237 & 177 & 1.91 & 16 \\
\hline & $2-4$ & 0.08 & 5.79 & 441 & 3.84 & 1.92 & 303 & 201 & 6.00 & 50 \\
\hline
\end{tabular}



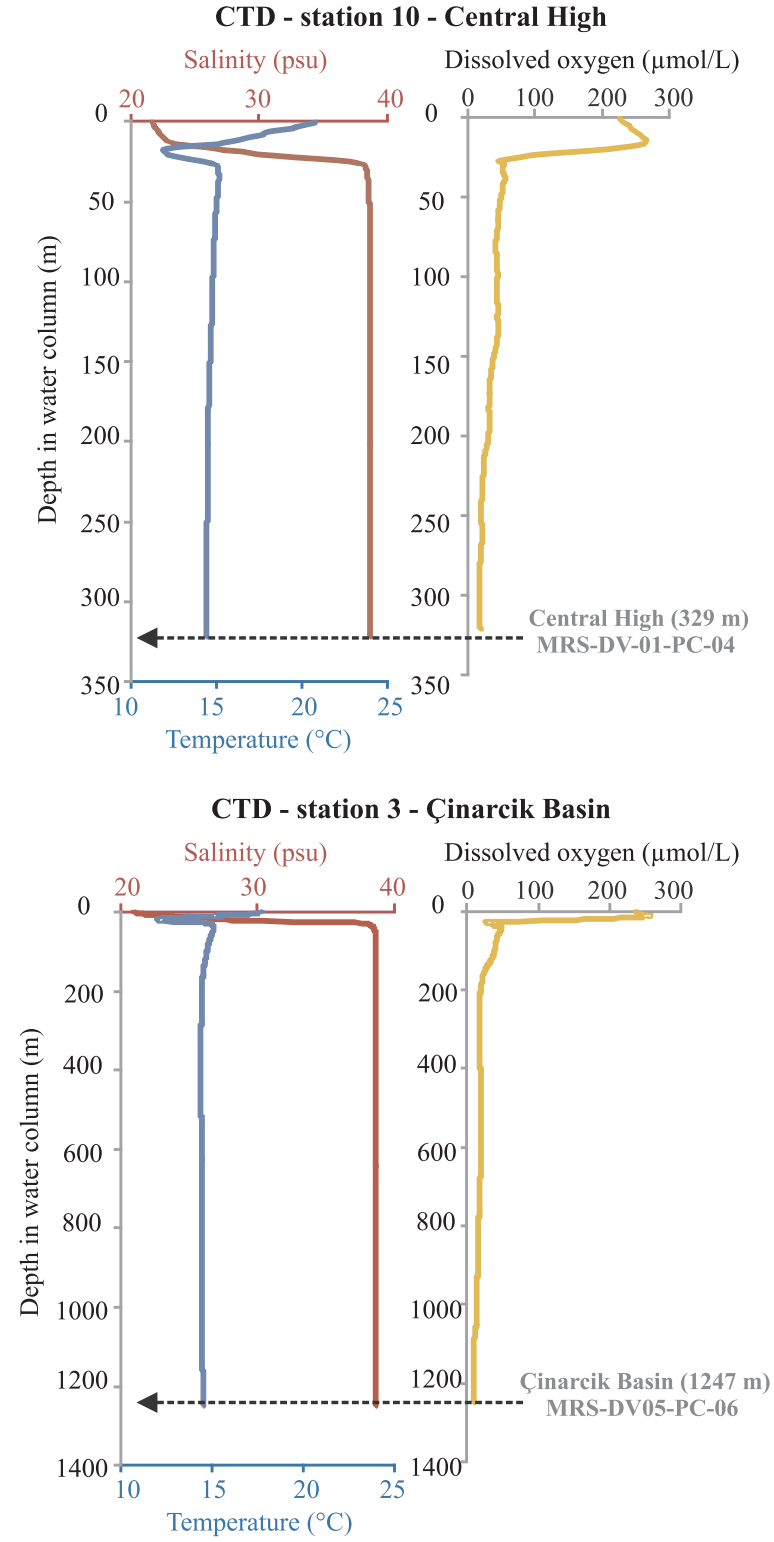

Fig. 2. CTD profiles of the water column at Central High and Çinarcik Basin (MARNAUT cruise sites MNT_CTD3 and MNT_CTD10 in Fig. 1) including bottom-water temperature, salinity and dissolved oxygen. Sampling depths of push cores indicated by black arrows. Data available online at http://www.ifremer.fr/sismer/index_FR.htm.

\section{Material and methods}

\subsection{Sediment cores}

Push cores were collected using the remote operated vehicle (ROV) Victor 6000 during two dives located on the Central High (MRS-DV59201 at $329 \mathrm{~m}$ water depth) and in the Çinarcik Basin (MRS-DV596-05 at $\sim 1240 \mathrm{~m}$ water depth) (Fig. 1) (Table 1). Both areas had been previously explored on several occasions (e.g., Géli et al., 2008; Zitter et al., 2008). A $25 \mathrm{~cm}$-long Plexiglas liner of $5.4 \mathrm{~cm}$ internal diameter was used within the corer to collect sediment samples (Fig. 3). Cores MRS-DV01-PC-02 and MRS-DV01-PC-04 were recovered on the Central High, and cores MRS-DV05-PC-04 and MRS-DV05-PC-06 in the Çinarcik Basin (Table 1). Color video was recorded on the ROV with the aim of providing a visual description of the sampling environment (Fig. 3). Two long cores, MRS-CS-04 (638 cm long) and MRS-CS-17 (1050 cm long), were also recovered with a Calypso piston corer at the two sites to analyze major and minor elemental content of pore waters (Table 2).
The Calypso cores additionally provided an environmental overview of the Central High and the south Çınarcık Basin in terms of major diagenetic processes. Readers should keep in mind that the MRS-CS-17 calypso core and the MRS-DV05-PC-04 push core are located $4.8 \mathrm{~km}$ away from the MRS-DV05-PC-06 push core used for foraminiferal investigations.

\subsection{Benthic foraminiferal analysis}

Each push core dedicated to foraminiferal study (MRS-DV01-PC-04 and MRS-DV05-PC-06) was sampled every $0.5 \mathrm{~cm}$ from the sedimentwater interface to $2 \mathrm{~cm}$, and then every centimetre between $2-5 \mathrm{~cm}$. Sediment samples were transferred into $250 \mathrm{~cm}^{3}$ bottles, which were filled with 95\% ethanol containing $2 \mathrm{~g} / \mathrm{L}$ Rose Bengal stain, commonly used to identify live foraminifera (Murray and Bowser, 2000; Walton, 1952). All samples were gently shaken for several minutes to obtain a homogeneous mixture. One month after the cruise, samples were sieved through 63 and $125 \mu \mathrm{m}$ sieves and the sieved residues were stored in 95\% ethanol. Because Rose Bengal might stain the protoplasm of dead foraminifera preserved under the generally prevailing anoxic sediment conditions (Corliss and Emerson, 1990; Bernhard, 2000), only fully stained foraminifera (all chambers except the last one stained bright pink) belonging to both size fraction (i.e., $63 \mu \mathrm{m}$ and $>125 \mu \mathrm{m}$ ) were sorted out from wet samples and stored in Plummer cells. Strict staining criteria were applied and doubtful individuals without perfectly stained tests were not included. Most live foraminifera were identified at species level (see Appendices A-B). At each station, we calculated diversity indices including species richness $S$ (representing the number of taxa), Shannon index H' (log base e), Evenness Index E, Dominance Index D and Berger-Parker Index (Hayek and Buzas, 1997; Murray, 2006) (Table 3). We obtained digital photographs of major species using a scanning electron microscope at Ifremer (FEI QUANTA 200 equipped with an Oxford Instrument Energy Dispersive Spectroscopy) (Fig. 4).

\subsection{Trace elements analysis in foraminiferal tests}

Because foraminifera were presumed alive (stained) at collection, the rigorous cleaning procedure required for dead/fossil specimens was not necessary. Instead, the modified cleaning procedure described in Dissard et al. (2009, 2010a,b) was adopted. Organic matter was removed by soaking specimens for $30 \mathrm{~min}$ in a $3-7 \% \mathrm{NaOCl}$ solution before analysis (Gaffey and Brönnimann, 1993). A stereomicroscope was used during the cleaning procedure to check optically for contamination and possible damage to the foraminiferal tests. Specimens were removed from the cleaning solution directly after complete bleaching. After cleaning, samples were thoroughly rinsed with deionized water to ensure complete removal of reagents. Individuals belonging to foraminiferal species Globobulimina affinis and Bolivina vadescens were selected for trace element analysis (Appendix C). Only the last chamber (F) was investigated. Single chambers were ablated using an Nd-YAG Laser (NWR-213, New Wave, ESI) inside an ablation chamber flushed with Helium $(0.7 \mathrm{~L} / \mathrm{min})$. Then the ablated sample with Helium was mixed with an Argon flow $(0.6 \mathrm{~L} / \mathrm{min})$ and transported to an Inductively Coupled Plasma Mass Spectrometry (ICP-MS). Pulse repetition rate was set at $10 \mathrm{~Hz}$, with an energy density at the sample surface of $30 \mathrm{~J} / \mathrm{cm}^{2}$. Ablation craters were $50 \mu \mathrm{m}$ in diameter and ablated material was analyzed with respect to time (and hence depth) using an ICP-MS (7500cx Agilent). Due to chamber size limitations, only one measurement was performed per $\mathrm{F}$ chamber for $B . v a-$ descens specimens but two ablations were performed on $G$. affinis $\mathrm{F}$ chambers. Average values of these measurements are presented in Appendix C. Analyses were calibrated against NIST SRM 610 glass, using the concentration data of Pearce et al. (1997) with ${ }^{43} \mathrm{Ca}$ as an internal standard. Concentrations of $\mathrm{Mg}, \mathrm{Sr}, \mathrm{Ba}$ and $\mathrm{Mn}$ were calculated using ${ }^{24} \mathrm{Mg},{ }^{88} \mathrm{Sr},{ }^{138} \mathrm{Ba}$ and ${ }^{55} \mathrm{Mn}$. An in-house matrix matched carbonate standard was used to verify potentially different ablation behavior 


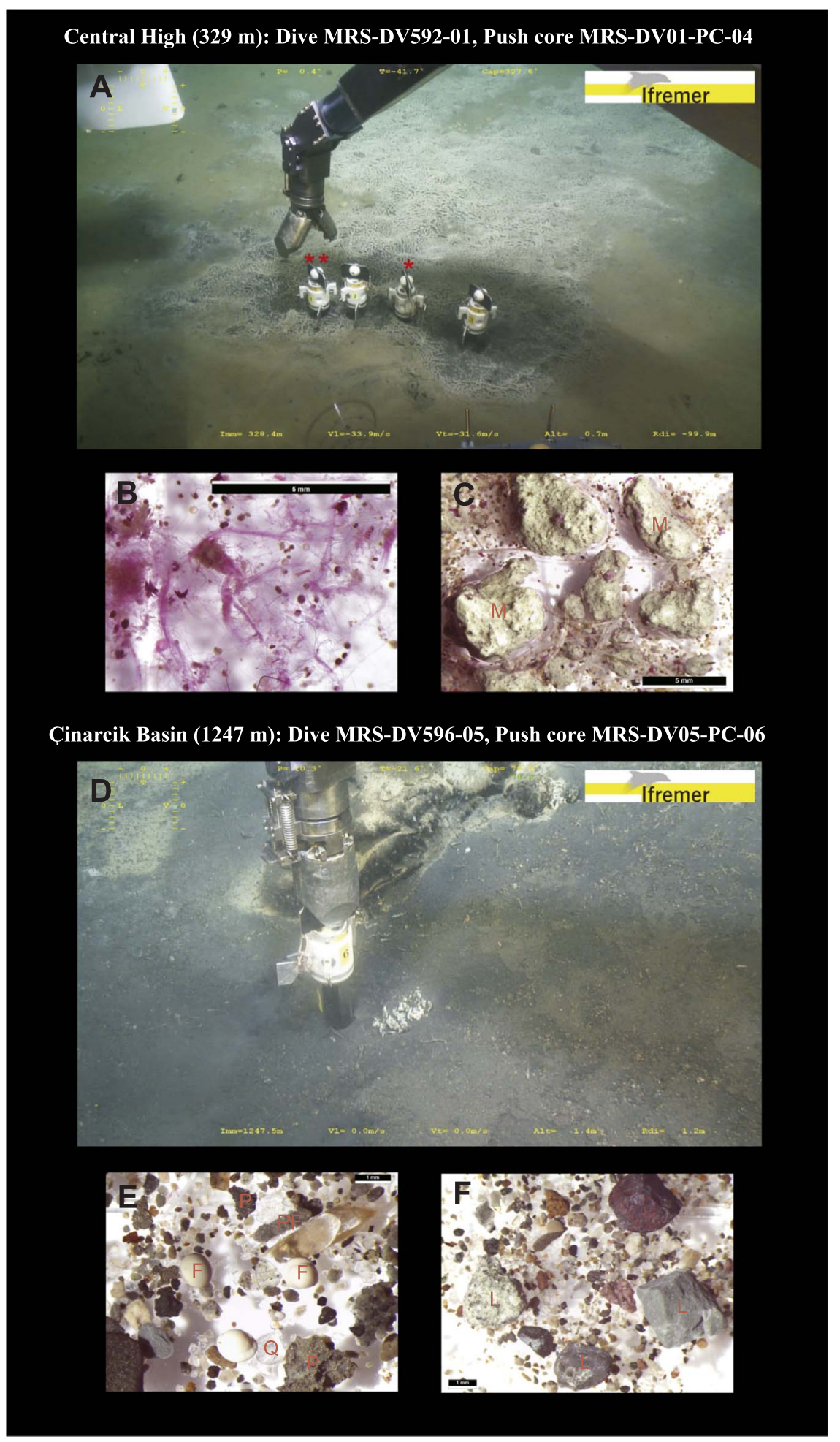

Fig. 3. A. Video stills of push core sampling at Central High (Dive MSR-DV592-01, depth $329 \mathrm{~m}$ ). Dedicated to sedimentary organic matter investigation, push core MRS-DV01-PC-02 is indicated by a single red asterisk. Push core MRS-DV01-PC-04 was dedicated to foraminiferal investigation and is indicated by two red asterisks. Note the large, white filamentous microbial mat. B, C. Stereoscopic views of sieve residues ( $>125 \mu \mathrm{m}$ ) collected at push core site MRS-DV01-PC-04 (depth $329 \mathrm{~m}$ ). "M" indicates a carbonate mudclast. D. Video stills of push core sampling at the south Çinarcik Basin (Dive MSR-DV596-05, push core MRS-DV05-PC06 , depth $1247 \mathrm{~m}$ ). Note the carbonate crust in the background and patchy coloration of surface sediment. E, F. Stereoscopic views of sieve residues ( $>125 \mu \mathrm{m}$ ) collected at push core site MRS-DV05-PC-06. "F" indicates dead foraminifera; "P" indicates pyrite; "PF" pyritised foraminifera; "Q" quartz grain and "L" lithoclast.

for glass and carbonate. Simultaneously monitoring the $\mathrm{Al}$ allowed us to discard contaminated profiles, or part of the profiles, from further elemental concentration calculations.

\subsection{Isotopic measurements $\left(\delta^{13} \mathrm{C}\right.$ and $\left.\delta^{18} \mathrm{O}\right)$ on foraminiferal tests}

Globobulimina affinis and Bolivina vadescens were selected for stable isotope measurements (Table 4). Bulk foraminifera samples were reacted with orthophosphoric acid at $70{ }^{\circ} \mathrm{C}$ for $180 \mathrm{~s}$ in individual vessels with an automated cryogenic distillation system (Kiel IV device), interfaced with a DeltaVAdvantage Isotope Ratio Mass Spectrometry (IRMS). Over the period of analysis, 20 runs of our laboratory's internal carbonate standard (Marbre LM) gave an average $\delta^{13} \mathrm{C}$ value of $2.117 \%$ $\pm 0.022 \%$ o $(<0.03 \% 0)(k=1)$ (theoretical value normalized to NBS $19=2.13 \%$ ) and an average $\delta^{18} \mathrm{O}$ value of $1.865 \%$ o $\pm \pm 0.051 \% 0(<0.06 \%)(k=1)$ (theoretical value normalized to NBS $19=-1.83 \%$ ). The analytical precision within each run, calculated from 1 to 20 measurements of the standard Marbre LM, varies from 2.079 to $2.162 \%$ for $\delta^{13} \mathrm{C}$ and from -1.769 to $-1.949 \%$ 。 for $\delta^{18} \mathrm{O}$. 
Table 2

Coordinates, sampling depth and core length of Calypso cores studied in this paper.

\begin{tabular}{llllll}
\hline Site & $\begin{array}{l}\text { Calypso } \\
\text { Core } \\
\text { reference }\end{array}$ & Latitude (N) & Longitude (E) & Depth (m) & Lenght (cm) \\
\hline Central High & $\begin{array}{l}\text { MRS-CS- } \\
04\end{array}$ & $40^{\circ} 51.7^{\prime}$ & $28^{\circ} 35.0^{\prime}$ & 326 & 638 \\
$\begin{array}{c}\text { South Çinarcik } \\
\text { Basin }\end{array}$ & $\begin{array}{l}\text { MRS-CS- } \\
17\end{array}$ & $40^{\circ} 43.0^{\prime}$ & $29^{\circ} 06.7^{\prime}$ & 1237 & 1060 \\
\hline
\end{tabular}

Table 3

Foraminiferal density and assemblage diversity indices (S, H', E, D and Berger-Parker) for both Central High and Çinarcik Basin (MRS-DV01-PC-04 and MRS-DV05-PC-06 cores respectively). Standing stocks are normalized for a $100 \mathrm{~cm}^{2}$ surface area. Two size fractions ( $63 \mu \mathrm{m}$ and $>125 \mu \mathrm{m})$ were investigated.

\begin{tabular}{|c|c|c|c|c|}
\hline & \multicolumn{2}{|c|}{$\begin{array}{l}\text { Central High, } 329 \text { m depth } \\
\text { MRS-DV592-01 MRS-DV01- } \\
\text { PC-04 }\end{array}$} & \multicolumn{2}{|c|}{$\begin{array}{l}\text { South Çinarcik Basin, } 1247 \mathrm{~m} \\
\text { depth } \\
\text { MRS-DV596-05 MRS-DV05-PC- } \\
06\end{array}$} \\
\hline & $63-125 \mu \mathrm{m}$ & $>125 \mu \mathrm{m}$ & $63-125 \mu \mathrm{m}$ & $>125 \mu \mathrm{m}$ \\
\hline Species Richness S & 8 & 9 & 2 & 3 \\
\hline Individuals/core & 1347 & 184 & 46 & 8 \\
\hline $\begin{array}{l}\text { Standing stocks } \\
\qquad\left(\mathrm{No} / 100 \mathrm{~cm}^{2}\right)\end{array}$ & 5885 & 804 & 201 & 35 \\
\hline $\begin{array}{l}\text { Dominance } \\
\text { Index D }\end{array}$ & 0.89 & 0.65 & 0.96 & 0.41 \\
\hline Shannon Index H' & 0.29 & 0.83 & 0.10 & 0.97 \\
\hline Evenness Index E & 0.17 & 0.26 & 0.56 & 0.88 \\
\hline $\begin{array}{l}\text { Berger-Parker } \\
\text { Index }\end{array}$ & 0.94 & 0.80 & 0.98 & 0.50 \\
\hline
\end{tabular}

\subsection{Pore water analysis}

Pore waters were collected immediately after Calypso core retrieval with 5 or $10 \mathrm{~cm}$ rhizon samplers consisting of a hydrophilic, porous polymer tube $2.5 \mathrm{~mm}$ in diameter (MOM, Rhizospshere) (SeebergElverfeldt et al., 2005). Samples were collected every $20-30 \mathrm{~cm}$ in $10 \mathrm{~mL}$ cleaned syringes then transferred to $15 \mathrm{~mL}$ HDPE acid-cleaned vials. Sample splits for various analyses were performed under a laminar air flow bench before acidification with $15 \mu \mathrm{L}$ concentrated $\mathrm{HNO}_{3}$ (Ultrex II, JT Baker) onboard. Major dissolved elements ([ $\left.\mathrm{SO}_{4}{ }^{2-}\right]$, $\left[\mathrm{Mg}^{2+}\right]$ ) were analyzed by ionic chromatography with a Dionex ICS5000 . The resulting concentrations were obtained within $\pm 1 \%$ accuracy with reference to the IAPSO seawater standard. $\left[\mathrm{Sr}^{2+}\right],\left[\mathrm{Mn}^{2+}\right]$, $\left[\mathrm{Ba}^{2+}\right]$ were measured by High Resolution Inductively Coupled Plasma Mass Spectrometry (HR-ICP-MS) (Element 2, Thermofisher) at Pole Spectrometrie Ocean (PSO, IUEML Brest). Sample volumes of $0.120 \mathrm{~mL}$ were diluted 25 times prior to introduction into the ICPMS. Calibrations were done in two ways; for Sr, a standard addition method was done with gravimetric standards at 4, 5.8, 11.8 and $15.5 \mathrm{mg} / \mathrm{L}$. For $\mathrm{Mn}$ and $\mathrm{Ba}$, a seawater standard NASS-5 (CNRC) with reported values $\left(\left[\mathrm{Mn}^{2+}\right]\right.$ $=0.919 \mu \mathrm{g} / \mathrm{L}, \mathrm{NRCC}$ certificate and $\left.\left[\mathrm{Ba}^{2+}\right]=5.1 \mu \mathrm{g} / \mathrm{L}\right)$ was employed (Field et al., 2007). Total alkalinity was evaluated using the $\mathrm{HCl}$ titration method (Titrino 888, Metrohm). For each measurement series, the pH-meter was calibrated with buffers pH 4 and 7 and the method's accuracy was evaluated using a seawater standard with certified alkalinity (Batch 123, University of San Diego, SCRIPPS). Calibrated aliquots of $0.1 \mathrm{M} \mathrm{HCl}$ were added to a sample volume of $1 \mathrm{~mL}$ until a pH of 4.3. Measurements of "Batch 123" gave $A_{T}=2232 \pm 220 \mu \mathrm{mol} / \mathrm{kg}$ ( $1 \mathrm{sd}, \mathrm{n}=10$ over 10 days) in coherence with the certified value $\left(\mathrm{A}_{\mathrm{T}}=\right.$ $2225.21 \pm 0.34 \mu \mathrm{mol} / \mathrm{kg}$ ).

\subsection{Rock-Eval pyrolysis}

Five samples from core MRS-DV01-PC-02 and four samples from core MRS-DV05-PC-04 were analyzed via the Rock-Eval thermal analysis technique, using a RE6 Turbo device (Vinci Technologies). Details of the RE6 apparatus are described in Behar et al. (2001). Analyses were carried out using the basic operating principles for testing recent marine sediments (Baudin et al., 2015). The RE6 technique provided measurements from the sequential pyrolysis and oxidation of about $40 \mathrm{mg}$ of desalted crushed sample. Briefly, this technique provides several fundamental parameters; the first peak (S1) corresponds mainly to free hydrocarbons that are volatilized for $3 \mathrm{~min}$ at $180{ }^{\circ} \mathrm{C}$ and detected by a Flame Ionization Detector (FID). The second peak (S2) represents hydrocarbons generated from kerogen cracking between $180{ }^{\circ} \mathrm{C}$ and $650{ }^{\circ} \mathrm{C}$. The amounts of $\mathrm{CO}_{2}$ and $\mathrm{CO}$ released during pyrolysis are detected by an infra-red (IR) cell and represent the S3 and S3CO peaks respectively. All these parameters are expressed in mg of hydrocarbons or $\mathrm{CO}_{2} / \mathrm{CO}$ per gram of rock. The temperature of maximum hydrocarbon yield by kerogen is called Tmax (in ${ }^{\circ} \mathrm{C}$ ). The residual organic and inorganic carbon content (in wt\%) is obtained by combustion in air from $300{ }^{\circ} \mathrm{C}$ to $850{ }^{\circ} \mathrm{C}$. The $\mathrm{CO}_{2}$ and $\mathrm{CO}$ issuing from this combustion are also detected by an IR cell and correspond to peaks S4 and $\mathrm{S} 5$ for $\mathrm{CO}_{2}$ and peak $\mathrm{S} 4 \mathrm{CO}$ for $\mathrm{CO}$. From these basic parameters, the total organic carbon content (TOC, in wt\%) is calculated as the sum of pyrolyzed and residual organic carbon. The hydrogen index (HI) corresponds to the quantity of pyrolyzable organic compounds from S2 relative total organic carbon (in mg HC. $\mathrm{g}^{-1} \mathrm{TOC}$ ) and the oxygen index (OI) to the $\mathrm{S} 3$ relative total organic carbon (in $\mathrm{mg} \mathrm{CO}_{2} \cdot \mathrm{g}^{-1} \mathrm{TOC}$ ). Finally, the mineral carbon (MinC) is also calculated on the basis $\mathrm{S}^{\prime}$ ' and S3' $\mathrm{CO}+\mathrm{S} 5$ peaks. This MinC can be converted to $\mathrm{CaCO}_{3}$ if we assume that all inorganic carbon is under the form of calcite or aragonite. The precision for the parameters is $\pm 0.1 \%$ for TOC, $\pm 0.05 \%$ for MinC, \pm $2{ }^{\circ} \mathrm{C}$ for Tmax, $\pm 10 \mathrm{mg} \mathrm{HC} . \mathrm{g}^{-1} \mathrm{TOC}$ for $\mathrm{HI}$ and $\pm 5 \mathrm{mg} \mathrm{CO} 2 . \mathrm{g}^{-1} \mathrm{TOC}$ for OI. All results are reported in Table 5.

\section{Results}

\subsection{Observations by ROV and sieve residues description}

At the Central High site, the seafloor was characterized by a large bacterial mat composed of whitish microbial filaments (Fig. 3). Push core MRS-DV01-PC-01 sampled within this mat (Fig. 3A) and accordingly, sieve residues ( $>125 \mu \mathrm{m}$ ) revealed Rose Bengal stained microbial filaments, but also abundant meiofauna and bioclasts (e.g., valves, radioles) (Fig. 3B-C). Filaments were abundant only in the first centimetre and concentrated within the first half centimetre. Some millimetric carbonate mudclasts were observed in the $2-3 \mathrm{~cm}$ interval. In the south Çinarcik Basin, the seafloor was characterized by protruding carbonate crusts surrounded by white to brown concretions and coarse sediments colored with black patches. Push core MRS-DV05-PC-06 was retrieved proximal to a carbonate crust (Fig. 3D). Sieve residues $(>125 \mu \mathrm{m}$ ) revealed large lithoclasts (related to various crystalline rocks), millimetric minerals (e.g., quartz), pyrite-enriched aggregates and pyritised foraminifera (Fig. 3E-F). The largest lithoclast $(2 \mathrm{~cm}$ ) was recorded between 2 and $4 \mathrm{~cm}$ depth.

\subsection{Sedimentary organic matter in push cores}

Total Organic Carbon (TOC) contents range from 1.3 to $2.9 \mathrm{wt} \%$ with higher values recorded in the south Çinarcik Basin (Table 7). Tmax values are always low $\left(\sim 418{ }^{\circ} \mathrm{C}\right.$ on average). $\mathrm{HI}$ values fluctuate from 162 to $303 \mathrm{mg}$ HC. ${ }^{-1}$ TOC along the studied cores, whereas OI values range between 128 and $201 \mathrm{mg} \mathrm{CO} \cdot \mathrm{g}^{-1}$ TOC. 


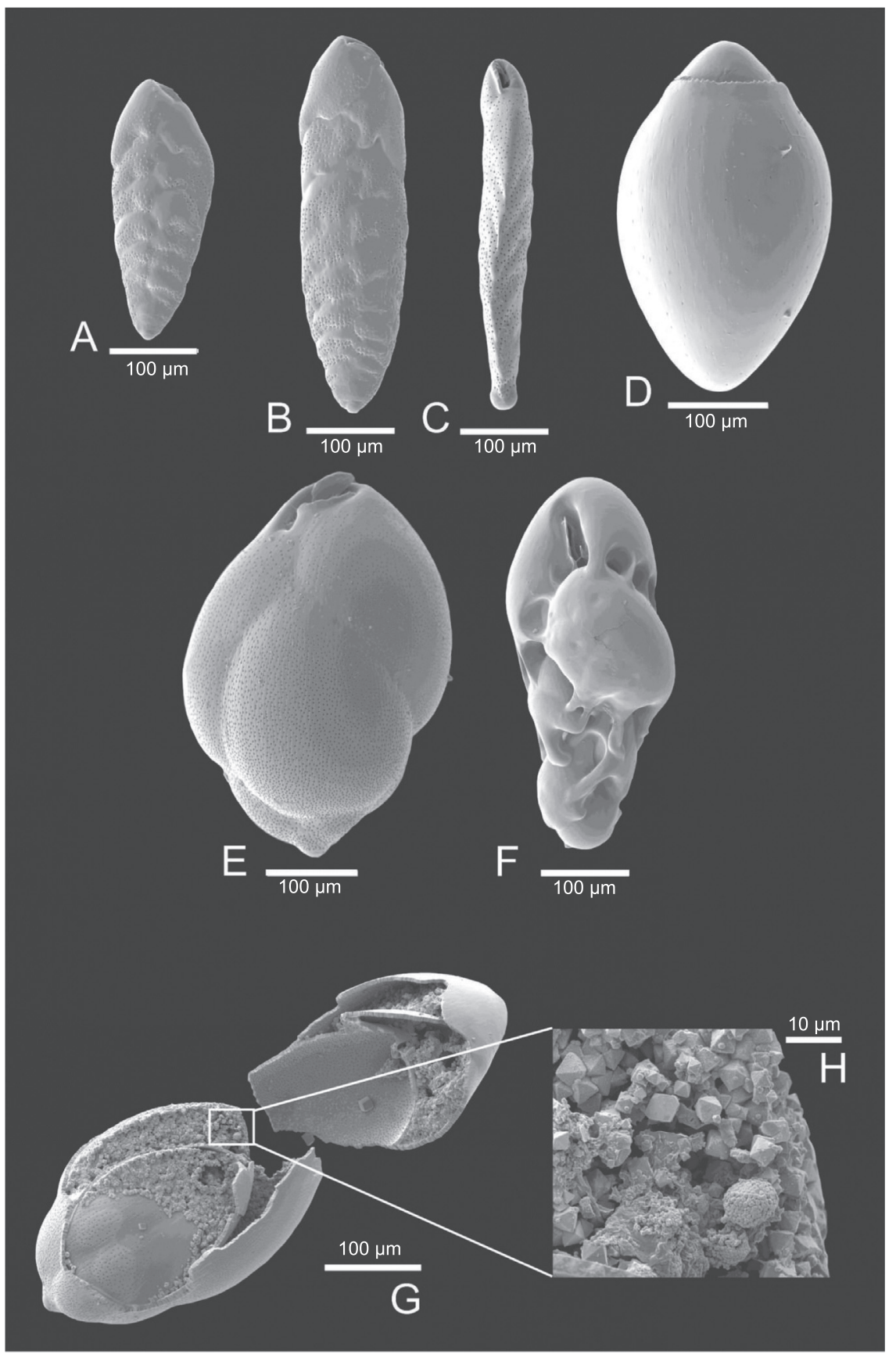

Fig. 4. SEM photographs of dominant foraminiferal species documented at Central High and Çinarcik Basin. A-C. Bolivina vadescens (MRS-DV01-PC-04), lateral (A, B) and profile (C) views. D. Chilostomella ovoidea (MRS-DV01-PC-04) lateral view. (E) Globobulimina affinis (MRS-DV01-PC-04) lateral view. (F) Virgulinella fragilis (MRS-DV01-PC-04) profile view. (G, H) Dead G. affinis infilled with pyrite (MRS-DV05-PC-06) with a close-up $(\mathrm{H})$ of octahedral and framboidal pyrite forms.

\subsection{Pore water geochemistry in Calypso cores}

In the Central High, dissolved strontium is relatively constant $(90 \mu \mathrm{M})$ along the core MRS-CS-04 (Fig. 5). Dissolved magnesium is $60 \mu \mathrm{M}$ in the uppermost $2 \mathrm{~m}$ and decreases slightly to $\sim 40 \mu \mathrm{M}$ down to $4.7 \mathrm{~m}$. Dissolved manganese shows a slight increase in the uppermost part of the core, with values reaching $16 \mu \mathrm{M}$ at $30 \mathrm{~cm}$ depth. Dissolved barium is lower than $1 \mu \mathrm{M}$ along the uppermost $\sim 3 \mathrm{~m}$ and then increases abruptly to $30 \mu \mathrm{M}$ at $4.7 \mathrm{~m}$. Sulfate concentration remains relatively constant $(\sim 30 \mathrm{mM})$ along the uppermost meter of the core, and decreases gradually to reach an almost null value at $4.4 \mathrm{~m}$ depth. Alkalinity increases downcore from $3,000 \mu \mathrm{M}$ to a $13000 \mu \mathrm{M}$

Table 4

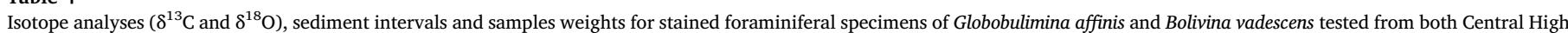

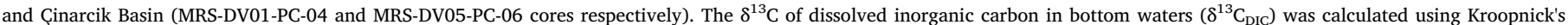
equation (Kroopnick, 1985). The $\delta^{18} \mathrm{O}$ of equilibrium calcite $\left(\delta^{18} \mathrm{O}_{\text {e.c. }}\right.$ ) was calculated following equations by O'Neil et al. (1969) and Friedman and O'Neil (1977).

\begin{tabular}{|c|c|c|c|c|c|c|c|}
\hline Push-core reference & Species & Sediment Interval & Weight ( $\mu \mathrm{g})$ & $\delta^{13} \mathrm{C}$ PDB (\%o) & $\delta^{18} \mathrm{O}$ PDB (\%o) & $\delta^{13} \mathrm{C}_{\mathrm{DIC}}$ PDB (\%o) & $\delta^{18} \mathrm{O}_{\text {e.c. }}$ PDB (\%o) \\
\hline MRS-DV01-PC-04 & Globobulimina affinis & $0.5-1 \mathrm{~cm}$ & 24 & -1.55 & 2.01 & -0.18 & 1.91 \\
\hline MRS-DV01-PC-04 & Bolivina vadescens & $0-0.5 \mathrm{~cm}$ & 20 & -2.34 & 1.44 & -0.18 & 1.91 \\
\hline MRS-DV05-PC-06 & Globobulimina affinis & $0.5-1 \mathrm{~cm}$ & 28 & -1.64 & 1.90 & -0.24 & 1.89 \\
\hline MRS-DV05-PC-06 & Bolivina vadescens & $0-0.5 \mathrm{~cm}$ & 20 & -2.11 & 1.68 & -0.24 & 1.89 \\
\hline
\end{tabular}


Table 5

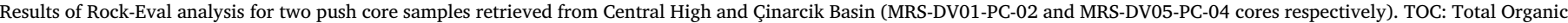
Carbon, HI: Hydrogen Index, OI: Oxygen Index. Refer to text for detailed descriptions of parameters.

\begin{tabular}{|c|c|c|c|c|c|c|c|c|c|c|}
\hline Push-core reference & $\begin{array}{l}\text { Interval } \\
(\mathrm{cm})\end{array}$ & $\begin{array}{l}\mathrm{S} 1 \\
(\mathrm{mg} / \mathrm{g})\end{array}$ & $\begin{array}{l}\mathrm{S} 2 \\
(\mathrm{mg} / \mathrm{g})\end{array}$ & $\begin{array}{l}\text { Tmax } \\
\left({ }^{\circ} \mathrm{C}\right)\end{array}$ & $\begin{array}{l}\text { S3 } \\
(\mathrm{mg} / \mathrm{g})\end{array}$ & $\begin{array}{l}\text { TOC } \\
(\%)\end{array}$ & $\begin{array}{l}\text { HI } \\
\text { (mg HC/g TOC) }\end{array}$ & $\begin{array}{l}\text { OI } \\
\mathrm{mg} \mathrm{CO} 2 / \mathrm{g} \text { TOC }\end{array}$ & $\begin{array}{l}\text { MinC } \\
(\%)\end{array}$ & $\begin{array}{l}\text { eq } \mathrm{CaCO} 3 \\
(\%)\end{array}$ \\
\hline \multirow[t]{5}{*}{ MRS-DV01-PC-02 } & $0-2$ & 0.04 & 5.05 & 424 & 3.25 & 2.35 & 215 & 138 & 2.17 & 18 \\
\hline & $1-2$ & 0.04 & 2.86 & 421 & 2.27 & 1.77 & 162 & 128 & 2.19 & 18 \\
\hline & $2-4$ & 0.08 & 2.88 & 417 & 2.32 & 1.73 & 166 & 134 & 2.05 & 17 \\
\hline & $4-6$ & 0.05 & 2.39 & 416 & 2.59 & 1.51 & 158 & 172 & 2.24 & 19 \\
\hline & $6-8$ & 0.08 & 1.99 & 411 & 1.92 & 1.43 & 140 & 135 & 2.24 & 19 \\
\hline \multirow[t]{4}{*}{ MRS-DV05-PC-04 } & $0-1$ & 0.08 & 6.75 & 406 & 5.05 & 2.86 & 237 & 177 & 1.91 & 16 \\
\hline & $2-4$ & 0.08 & 5.79 & 441 & 3.84 & 1.92 & 303 & 201 & 6.00 & 50 \\
\hline & $4-6$ & 0.05 & 3.58 & 413 & 3.42 & 1.87 & 192 & 183 & 3.43 & 29 \\
\hline & $6-8$ & 0.04 & 2.27 & 412 & 2.37 & 1.26 & 180 & 188 & 4.92 & 41 \\
\hline
\end{tabular}

concentration at $4.7 \mathrm{~m}$.

In the south Çinarcik Basin, Sr(II) concentration decreases from 95 to $60 \mu \mathrm{M}$ downcore along the uppermost $2 \mathrm{~m}$ (Fig. 5). Values then stay relatively close to $\sim 60 \mu \mathrm{M}$ down to $10 \mathrm{~m}$. $\mathrm{Mg}$ (II) concentration is relatively constant (values ranging between 60 and $50 \mu \mathrm{M}$ ). Mn(II) content is close to $160 \mu \mathrm{mol} / \mathrm{L}$ at a depth of $10 \mathrm{~cm}$, and decreases abruptly to $5 \mu \mathrm{M}$ at $190 \mathrm{~cm}$ and deeper. $\mathrm{Ba}(\mathrm{II})$ is lower than $2 \mu \mathrm{M}$ in the upper $1.3 \mathrm{~m}$ of core MRS-CS-17 but then increases with sediment depth to reach $47 \mu \mathrm{M}$ at $8.9 \mathrm{~m}$. Sulfate content decreases more abruptly than the shallower Central High site, with lower values recorded below $2.3 \mathrm{~m}$. Alkalinity increases more rapidly from $6000 \mu \mathrm{M}$ in the topmost sediment layer to $45,000 \mu \mathrm{M}$ at $4.7 \mathrm{~m}$.

\subsection{Foraminiferal faunas}

\subsubsection{Standing stocks and diversity}

The foraminiferal standing stocks of the $63 \mu \mathrm{m}$ size fraction varies from 200 individuals $/ 100 \mathrm{~cm}^{2}$ at the south Çinarcik Basin site (MRSDV05-PC-06, $1247 \mathrm{~m}$; Fig. 6 and Table 3) to 5900 individuals $/ 100 \mathrm{~cm}^{2}$ at the Central High site (MRS-DV01-PC-04, $329 \mathrm{~m}$ depth; Fig. 6 and Table 3). In the larger size fraction ( $>125 \mu \mathrm{m})$, standing stocks are lower with values of 35 individuals $/ 100 \mathrm{~cm}^{2}$ at the deeper Çinarcik Basin to 800 individuals $/ 100 \mathrm{~cm}^{2}$ at the Central High site. Species richness (S) is extremely low at both sites and varies from 2 species recorded in the $63 \mu \mathrm{m}$ fraction at Çinarcik Basin to 9 species in the $>$ $125 \mu \mathrm{m}$ fraction at Central High (Fig. 7 and Table 3). The Shannon index $\left(H^{\prime}\right)$ is generally low $(<1)$, with lower values recorded for the smaller fraction (0.29 at Central High site and 0.10 at Çinarcik Basin). Accordingly, Berger-Parker index and Dominance index values are higher for the $63 \mu \mathrm{m}$ fraction than the $>125 \mu \mathrm{m}$ at both stations (Fig. 6 and Table 3).

\subsubsection{Foraminiferal composition and microhabitat}

At the Central High station, stained Bolivina vadescens $(94.5 \%)$ dominates the $63 \mu \mathrm{m}$ fraction with Virgulinella fragilis the second most abundant species (2.5\%). Their abundance peaks in the uppermost centimetre of sediment, common for shallow infaunal taxa (Fig. 7). In the larger size fraction ( $>125 \mu \mathrm{m}$ ), Globobulimina affinis is the dominant species (79.9\%) and occupies an intermediate to deep infaunal microhabitat. Virgulinella fragilis is again the second most abundant taxon $(8.7 \%)$ with the same shallow infaunal distribution. Large $B$. vadescens (3.3\%) specimens together with Chilostomella ovoidea (3.3\%), another intermediate to deep infaunal species, were recorded (Fig. 7).

At the Çinarcik Basin station, B. vadescens $(97.8 \%)$ dominates the $63 \mu \mathrm{m}$ fraction and inhabits the same sediment range as Central High. In the large size fraction, G. affinis (50\%) is dominant and inhabits an intermediate infaunal microhabitat. Bolivina vadescens accounts for $37 \%$ of the living fauna and occupies a shallow infaunal microhabitat. Chilostomella ovoidea (13\%) is the third most abundant taxon (Fig. 7).

\subsection{Geochemical signatures in foraminiferal tests}

\subsubsection{Trace elements}

For Bolivina vadescens, $\mathrm{Mg} / \mathrm{Ca}$ ratio ranges between $3.01-7.12 \mathrm{mmol} / \mathrm{mol}$ at the Central High station with an average value of $5.60 \mathrm{mmol} / \mathrm{mol}$. Slightly higher values varying from 4.72 to $7.61 \mathrm{mmol} / \mathrm{mol}$ (average of $5.89 \mathrm{mmol} / \mathrm{mol}$ ) are recorded at the Çinarcik Basin station (Fig. 8, Appendix C). Sr/Ca ratios at the Central High station vary from 1.05 to $1.47 \mathrm{mmol} / \mathrm{mol}$ with an average value of $1.37 \mathrm{mmol} / \mathrm{mol}$. Sr/Ca ratios range between $1.18-1.62 \mathrm{mmol} / \mathrm{mol}$ with an average value of $1.44 \mathrm{mmol} / \mathrm{mol}$ at the Çinarcik Basin station. Mn/ Ca ratios show a remarkable difference between both sampling sites with values of $24-1012 \mu \mathrm{mol} / \mathrm{mol}$ at the Central High station (average of $427 \mu \mathrm{mol} / \mathrm{mol}$ ), and $\mathrm{Mn} / \mathrm{Ca}$ ratios of $730-5657 \mu \mathrm{mol} / \mathrm{mol}$ at the Çinarcik Basin (average of $2352 \mu \mathrm{mol} / \mathrm{mol}$ ) (Fig. 8, Appendix C). Ba/Ca ratios are slightly higher at the Central High station with 5.99-67.73 $\mu \mathrm{mol} / \mathrm{mol}$ with an average value of $34.2 \mu \mathrm{mol} / \mathrm{mol}$ compared to values of $6.01-28.84 \mu \mathrm{mol} / \mathrm{mol}$ at the Çinarcik Basin with an average of 13.57 $\mu \mathrm{mol} / \mathrm{mol}$.

For G. affinis, $\mathrm{Mg} / \mathrm{Ca}$ and $\mathrm{Sr} / \mathrm{Ca}$ ratios do not show any major difference between both sites. $\mathrm{Mg} / \mathrm{Ca}$ ratios range from 14.35 to $16.42 \mathrm{mmol} / \mathrm{mol}$ (average of $15.06 \mathrm{mmol} / \mathrm{mol}$ ) at Central High and from 14.24 to $18.51 \mathrm{mmol} / \mathrm{mol}$ (average of $16.31 \mathrm{mmol} / \mathrm{mol}$ ) at Çinarcik Basin. Sr/Ca ratios vary from 1.12 to $1.25 \mathrm{mmol} / \mathrm{mol}$ (average of $1.19 \mathrm{mmol} / \mathrm{mol}$ ) at Central High, and $1.17-1.26 \mathrm{mmol} / \mathrm{mol}$ (average of $1.22 \mathrm{mmol} / \mathrm{mol}$ ) at Çinarcik Basin (Fig. 8; Appendix C). Mn/Ca ratios are higher in the Çinarcik Basin with $123.50-918.98 \mu \mathrm{mol} / \mathrm{mol}$ (average of $348.99 \mu \mathrm{mol} / \mathrm{mol}$ ), compared to Central High with 17.23-59.39 $\mu \mathrm{mol} / \mathrm{mol}$ (average of $41.69 \mu \mathrm{mol} / \mathrm{mol}$ ) (Fig. 8; Appendix C). $\mathrm{Ba} / \mathrm{Ca}$ ratios appear higher at Central High with values of 4.49-16.81 $\mu \mathrm{mol} / \mathrm{mol}$ (average of $9.97 \mu \mathrm{mol} / \mathrm{mol}$ ) compared to Çinarcik Basin with 3.11-7.42 $\mu \mathrm{mol} / \mathrm{mol}$ (average 4.35 of $\mu \mathrm{mol} / \mathrm{mol}$ ).

\subsubsection{Stable isotopes}

Foraminifera used for elemental concentrations were subsequently prepared to determine stable isotope ( $\mathrm{C}$ and $\mathrm{O}$ ) compositions. Due to the small quantity of carbonate available, one single bulk measurement was performed per species (GloboBulimina affinis and Bolivina vadescens) for each station (MRS-DV01-PC-04 and MRS-DV05-PC-06), averaging several foraminiferal tests per data point. Quantities of carbonate (foraminiferal test weight available) used for each of these measurements are reported next to stable isotope data in Table 4. At Central High, $B$. vadescens living in surface sediments $(0-0.5 \mathrm{~cm})$ presents a mean $\delta^{13} \mathrm{C}$ value of $-2.34 \%$ and a mean $\delta^{18} \mathrm{O}$ value of $+1.44 \%$. In comparison, $G$. affinis, living deeper within the sediment (here sampled from 0.5 to $1 \mathrm{~cm}$ ), presents a mean $\delta^{13} \mathrm{C}$ value of $-1.55 \%$ and a mean $\delta^{18} \mathrm{O}$ value of $+2.01 \%$ - higher values than $B$. vadescens. Similarly, at Çinarcik Basin, B. vadescens presents a mean $\delta^{13} \mathrm{C}$ value of $-2.11 \%$ and a mean $\delta^{18} \mathrm{O}$ value of $+1.68 \%$ whilst $G$. affinis an enriched mean $\delta^{13} \mathrm{C}$ value of $-1.64 \%$ and $\delta^{18} \mathrm{O}$ value of $+1.90 \%$. 
Central High (326 m): MRS-CS-04
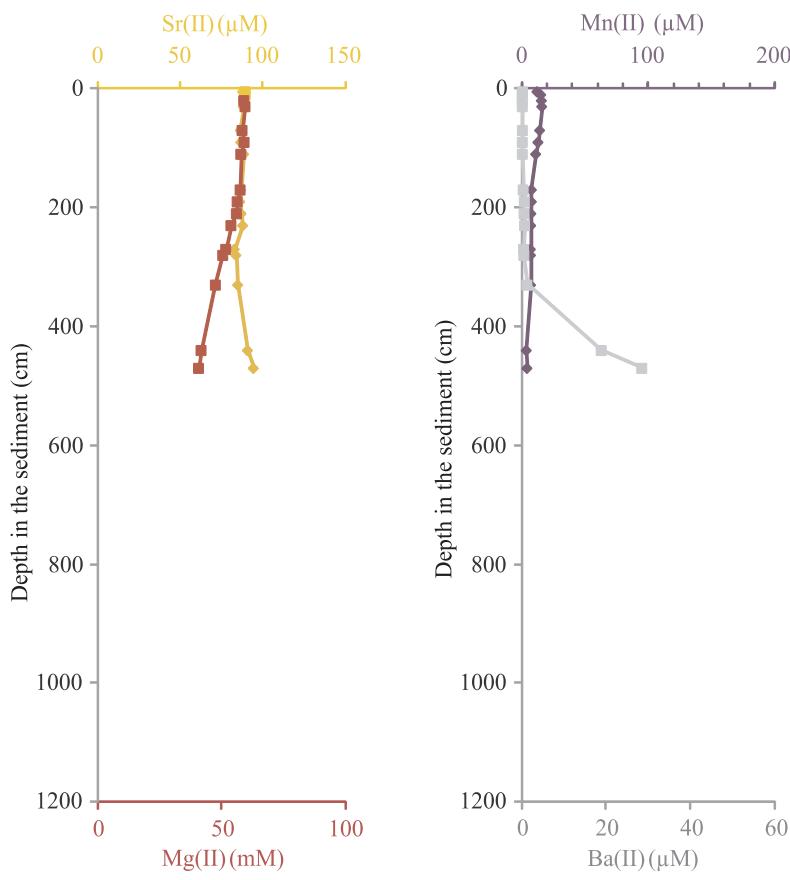

Çinarcik Basin (1237 m): MRS-CS-17
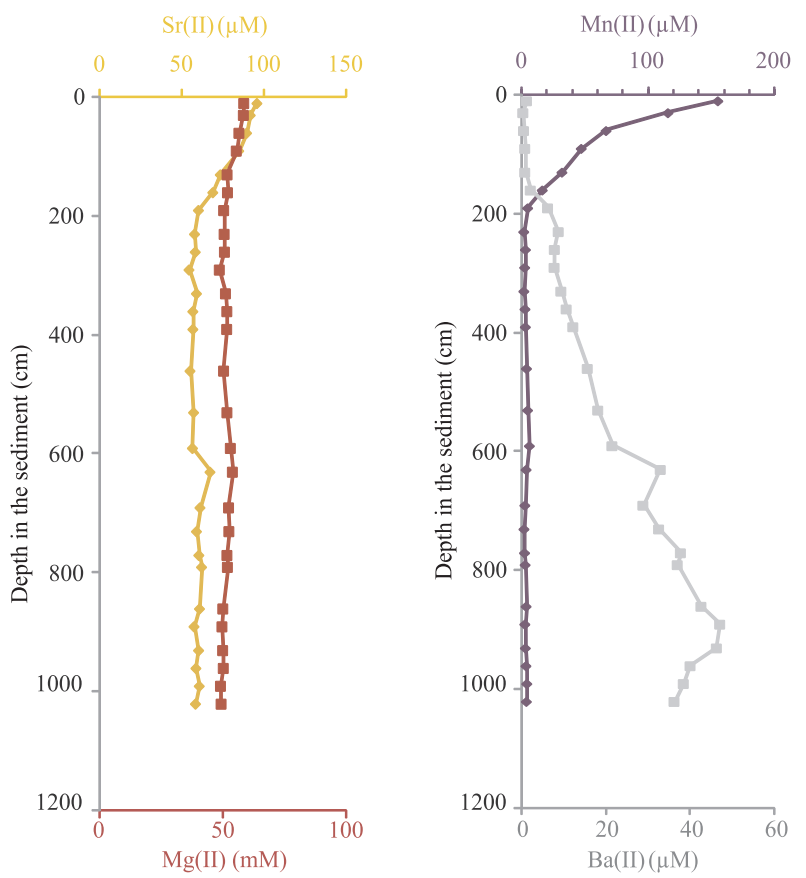

\section{Discussion}

\subsection{Environmental overview of the Central High and the south Çinarcik} Basin

Dysoxic ecosystems investigated in this paper were previously documented in other studies related to the MARNAUT oceanographic cruise (e.g., Géli et al., 2008; Zitter et al., 2008; Ritt et al., 2010; Chevalier et al., 2011; Crémière et al., 2012). Our ROV observations during the MARSITE cruise and newly acquired geochemical data confirm that localized cold seepages occur at both the Central High and south Çinarcik Basin (Figs. 3 and 5). Sulfate content profiles in long
Fig. 5. Pore water geochemistry from both MRS-CS04 and MRS-CS-17 Calypso cores collected at Central High and Cinarcik Basin respectively. Measured parameters include dissolved Strontium (Sr(II)), Magnesium ( $\mathrm{Mg}(\mathrm{II})$ ), Barium (Ba(II)), Manganese $(\mathrm{Mn}(\mathrm{II}))$, Sulfate $\left(\mathrm{SO}_{4}^{-}\right)$and Alkalinity.
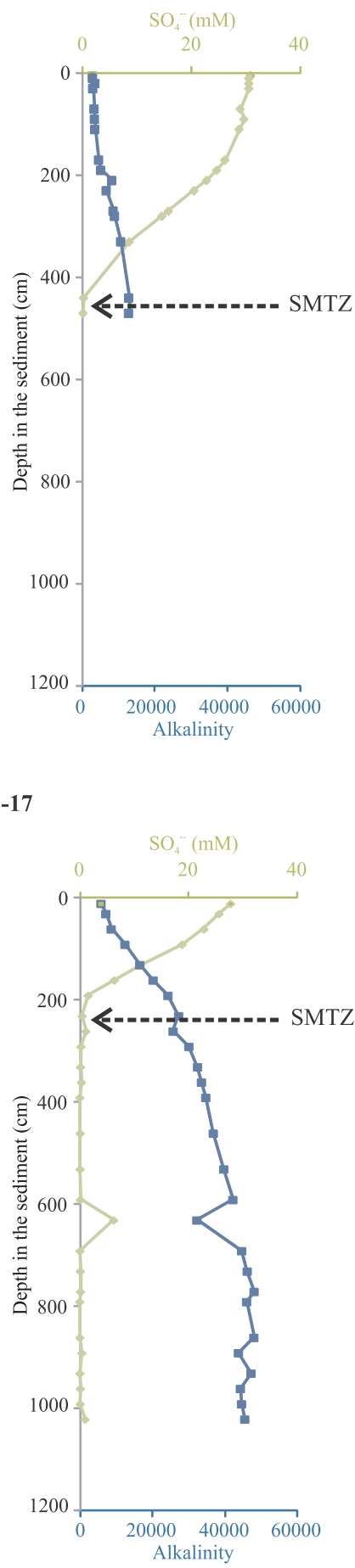

cores MRS-CS-04 (Central High) and MRS-CS-17 (south Çinarcik Basin) notably show a Sulfate-Methane Transition Zone (SMTZ) at depths of $4.4 \mathrm{~m}$ and $2.3 \mathrm{~m}$ below the seafloor, respectively. There, upward migrating methane is oxidized by a consortium of Archaea and sulfate reducing bacteria which results in hydrogen sulfide and alkalinity production (e.g., Ritt et al., 2010; Chevalier et al., 2011; Crémière et al., 2012; Ruffine et al., 2015) (Fig. 5). This reaction, known as the anaerobic oxidation of methane (AOM), occurs at a shallower depth at the south Çinarcik Basin (MRS-CS-17, $1237 \mathrm{~m}$ ) than that at Central High (MRS-CS-04, $326 \mathrm{~m}$ ), indicating a higher upward methane flux (Fig. 5). Higher sedimentation rates and more abundant biodegradable organic matter within the sediments could explain the enhanced diagenetic 


\section{Standing stocks}

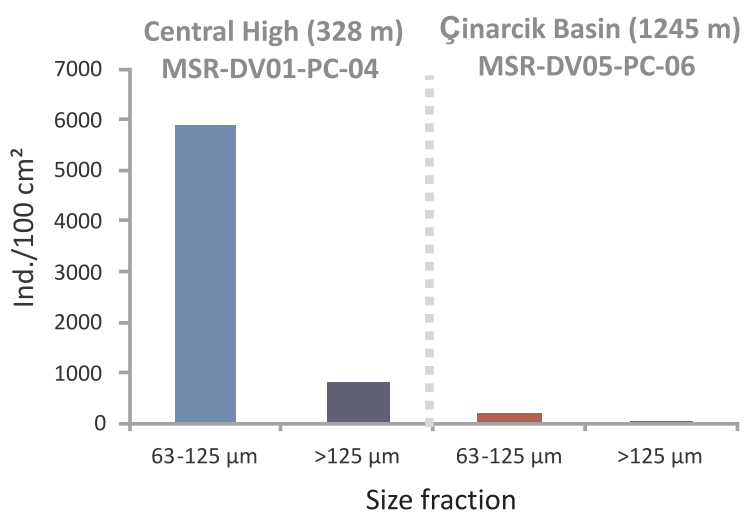

\section{Dominance Index D}

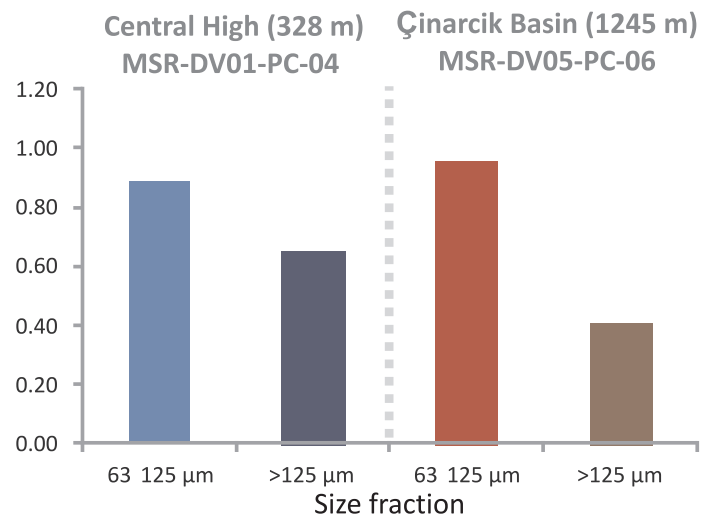

\section{Evenness Index E}

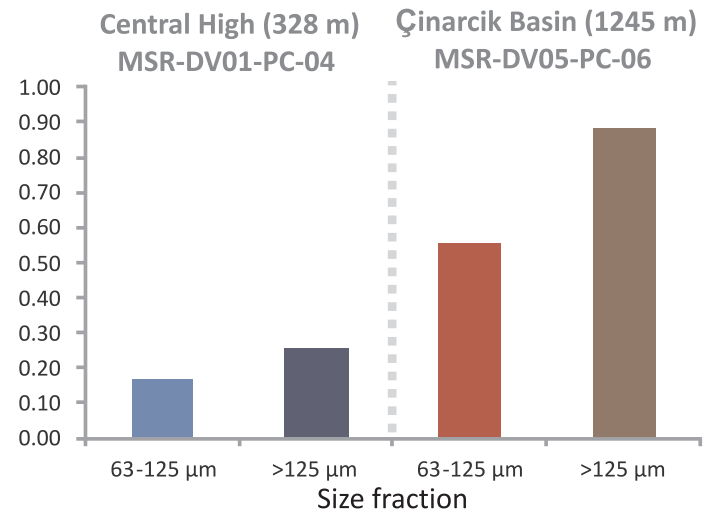

Species Richness (S)

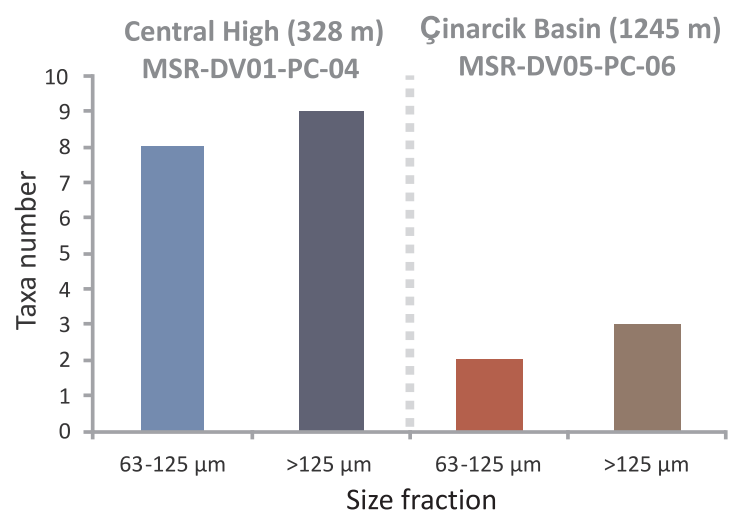

Shannon Index H'

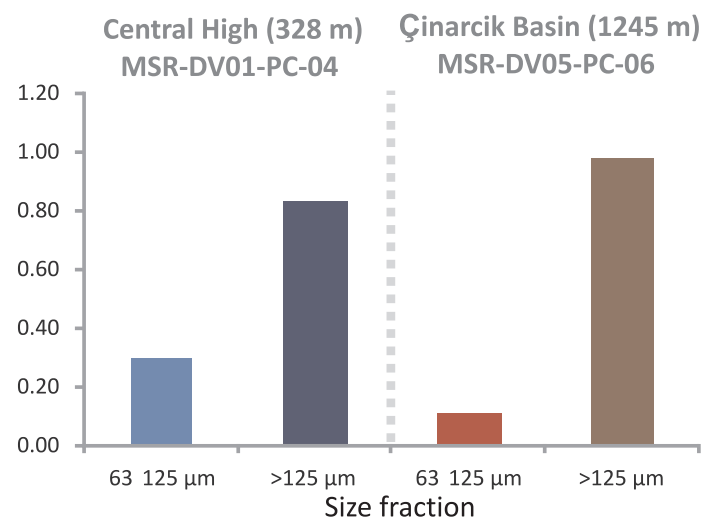

Berger-Parker Index

Central High (328 m) Çinarcik Basin (1245 m) MSR-DV01-PC-04

MSR-DV05-PC-06

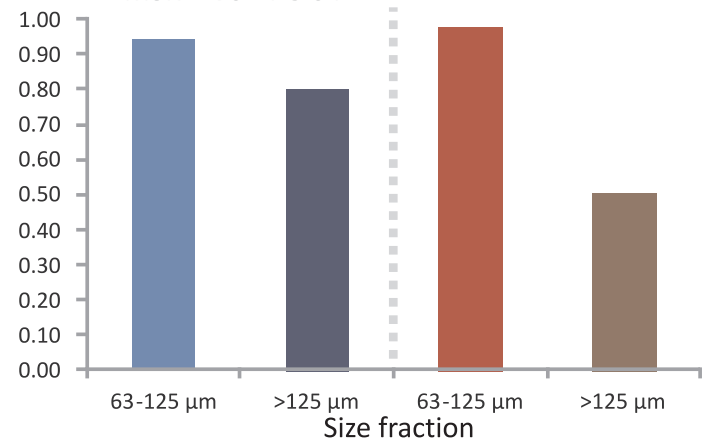

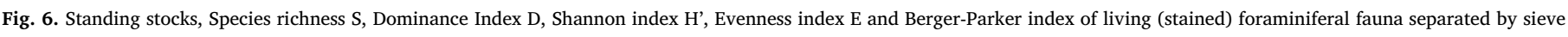
fraction $(63 \mu \mathrm{m}$ and $>125 \mu \mathrm{m})$ from push cores MRS-DV01-PC-04 (Central High) and MRS-DV05-PC-06 (south Çinarcik Basin).

reactions and methane oxidation in the deeper Çinarcik Basin (Çă̆atay et al., 2004). That being said, the large filamentous bacterial mat sampled at Central High suggests localized seepage of sulfide-enriched fluid, which may be generated by methane oxidation within subsurface sediments (De Prunelé, 2015). In restricted places where we collected push cores dedicated to foraminiferal study (MRS-DV01-PC-04, MRSDV05-PC-06), we did not record any gas bubble emission. This rules out that our push cores were affected by free methane gas flowing through the sediment-water interface.

Dissolved manganese profiles in both long cores MRS-CS-17 (south Çinarcik Basin) and MRS-CS-04 (Central High) are totally different from each other. Whereas $\mathrm{Mn}$ (II) shows a remarkable subsurface maximum $(160 \mu \mathrm{M})$ in the core MRS-CS-17, Mn(II) content in core MRS-CS-04 is an order of magnitude lower $(16 \mu \mathrm{M})$ (Fig. 5). According to Ergin
(1994), high concentrations of dissolved manganese in pore water in the Sea of Marmara's deep basins may reflect putative hydrothermal activities. Our pore water geochemical data does not show any hydrothermal seepage at the sampling sites. Alternatively, high content of dissolved Mn could be related to modern external inputs. Mn(IV) oxyhydroxide, which precipitates in oxygenated shelf environments, could be reworked from shallow-water areas and transported to the deep Çinarcik Basin (Anschutz et al., 2000; Mouret et al., 2008). Moreover, the Çinarcik Basin, like all deep Marmara sub-basins, are characterized by turbidite-homogenite layers, which may preferentially focus Mn(IV)bearing particles supplied from shallower, oxygenated areas (Mercierde-Lepinay et al., 2003; Çağatay, 2003; Çağatay et al., 2004; Beck et al., 2007) (Fig. 9). In this case, Mn(IV) oxyhydroxides would be reduced through organic matter mineralization, resulting in extremely high Mn 
Central High (329 m): Dive MSR-DV592-01, Push core MSR-DV01-PC-04

63-125 $\mu \mathrm{m}$

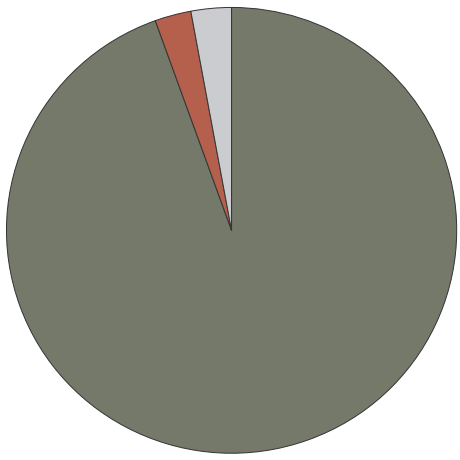

No. individuals $/ 50 \mathrm{~cm}^{3}$

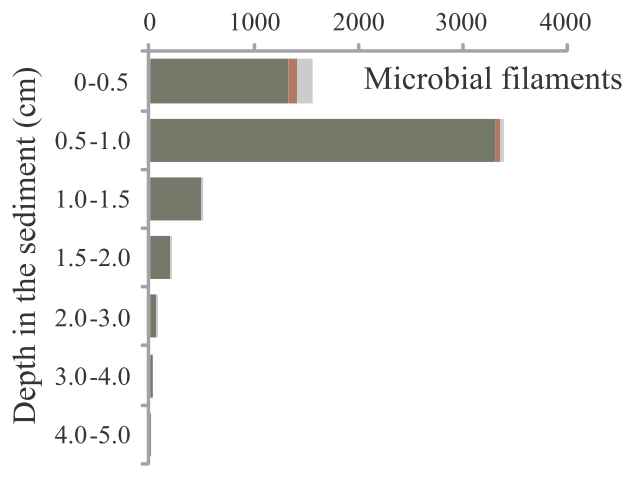

Bolivina vadescens

Chilostomella ovoidea

Globobulimina affinis

Virgulinella fragilis

Accessory taxa
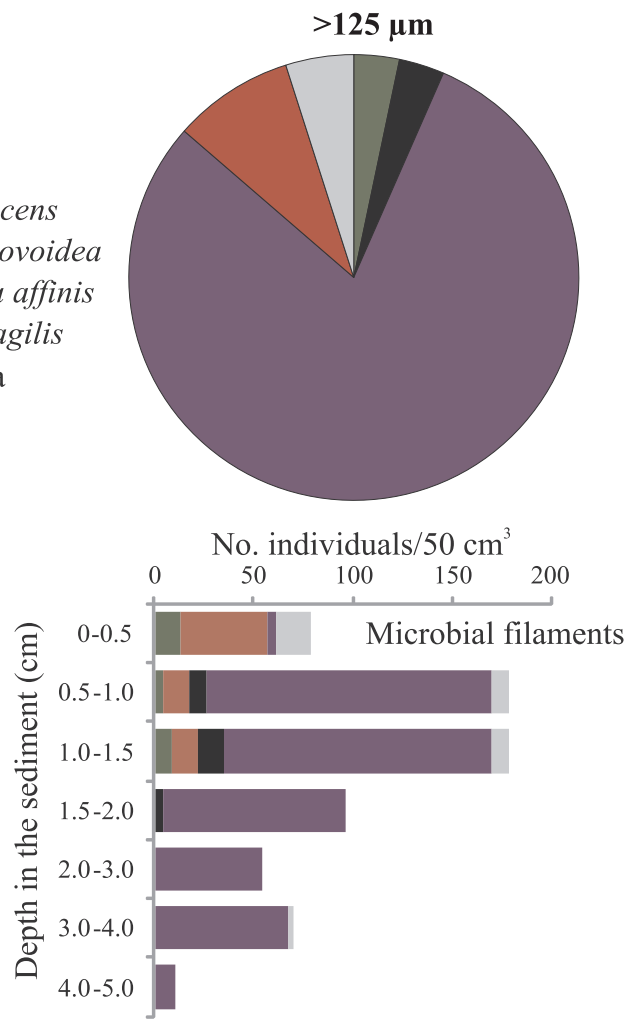

Çinarcik Basin (1247 m): Dive MSR-DV596-05, Push core MRS-DV05-PC-06

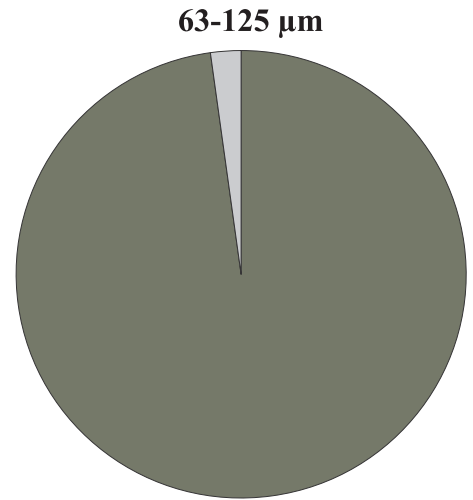

No. individuals $/ 50 \mathrm{~cm}^{3}$

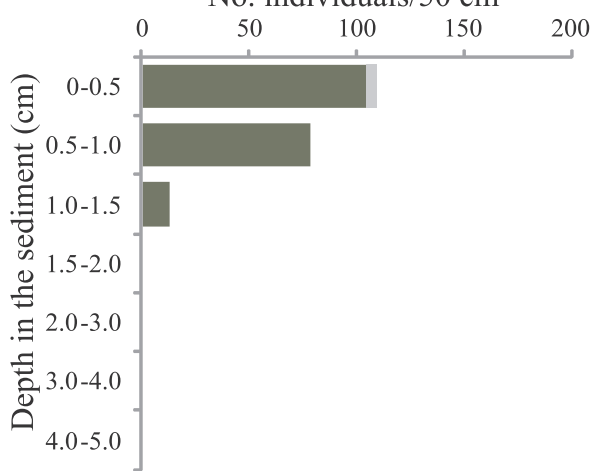

Bolivina vadescens

Chilostomella ovoidea

Globobulimina affinis

Virgulinella fragilis

Accessory taxa

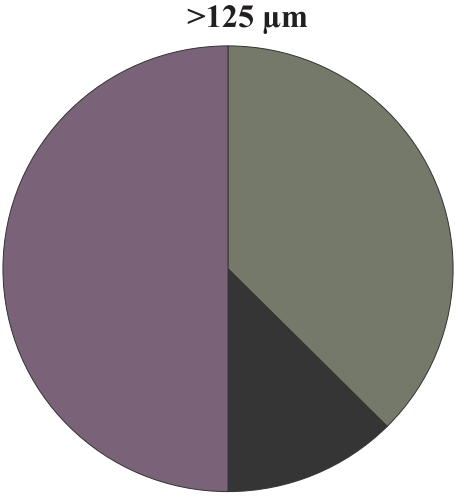

No. individuals $/ 50 \mathrm{~cm}^{3}$

$\begin{array}{lllll}0 & 50 & 100 & 150 & 200\end{array}$

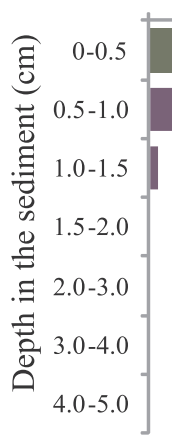

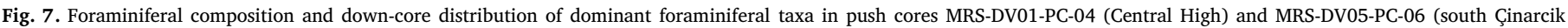
Basin). 


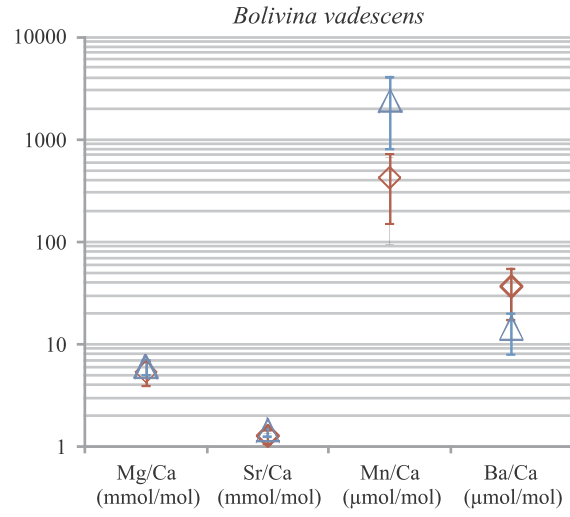

$\diamond \quad$ Central High (328 m) MSR-DV01-PC-04 $\mathrm{n}=11$

$\triangle$ Çinarcik Basin $(1245 \mathrm{~m})$ MSR-DV05-PC-06 $\mathrm{n}=7$

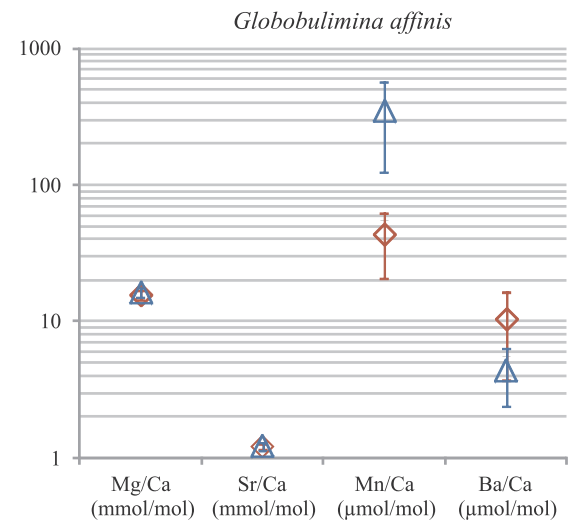

$\diamond \quad$ Central High (328 m) MSR-DV01-PC-04 $\mathrm{n}=3$

$\triangle$ Çinarcik Basin (1245 m) MSR-DV05-PC-06

Fig. 8. Trace elements ratios ( $\mathrm{Mg} / \mathrm{Ca}, \mathrm{Sr} / \mathrm{Ca}, \mathrm{Mn} / \mathrm{Ca}, \mathrm{Ba} / \mathrm{Ca}$ ) of living (stained) Bolivina vadescens and Globobulimina affinis from push cores MRS-DV01-PC-04 (Central High) and MRS-DV05-PC-06 (south Çinarcik Basin). " $n$ " indicates number of analyzed individuals (see Methods and Appendix C for further explanation). Error bars illustrate standard deviations.

(II) surface sediment content (Spencer and Brewer, 1971; Çă̆atay et al., 2004).

As previously documented in numerous studies (e.g., Çağatay et al., 2004; Géli et al., 2008; Zitter et al., 2008; Ritt et al., 2010; Chevalier et al., 2011; Crémière et al., 2012) and in combination with our results, both the Central High and the south Çinarcik Basin can be considered oxygen depleted areas characterized by remarkable spatial heterogeneity. This centimetre to kilometre-scale variability is expressed through (1) contrasted geochemical processes below the sedimentwater interface (e.g., enhanced sulfate reduction and dissolved manganese production in the deep basin), (2) various sedimentary facies (e.g., differences in sedimentation rates and gravity-related sedimentation) and (3) an obvious biozonation of benthic life (e.g. microbial mat).

\section{2. "Survivalist" foraminiferal faunas adapted to extreme ecosystems}

In deep-sea ecosystems, both spatial and temporal dynamics of benthic foraminifera are controlled by various physico-chemical parameters (see reviews by Gooday, 2003 and Jorissen et al., 2007). The organic-matter flux, related to either exported marine primary production or lateral advection of continental organic compounds, is a major ecological factor that constitutes a fundamental source of energy sustaining foraminiferal metabolic activity, growth, reproduction and biomineralization. However, the organic-matter flux acts indirectly as a limiting parameter when it provokes either temporary or long-term hypoxia near the sea floor and/or within the sediment (i.e. Oxygen Minimum Zone, OMZ) (e.g., Sen Gupta and Machain-Castillo, 1993; Jannink et al., 1998; Bernhard and Sen Gupta, 1999; Gooday et al., 2000; Kurbjeweit et al., 2000; Schumacher et al., 2007; Woulds et al., 2007; Mallon et al., 2012; Glock et al., 2012; Fontanier et al., 2014b;
Caulle et al., 2014). Consequently, in oxygen-depleted ecosystems, foraminiferal diversity is extremely low in the OMZ, and standing stocks generally high (e.g. Jannink et al., 1998; Gooday et al., 2000; Schumacher et al., 2007; Fontanier et al., 2014b; Caulle et al., 2014). In the Sea of Marmara, prevailing oxygen depletion in deep waters (i.e., below $25 \mathrm{~m}$ depth) is related to both water column stratification and organic matter export through the water column. Stratification is clearly illustrated by a strong halocline located at a depth of $25 \mathrm{~m}$, which corresponds perfectly to an abrupt oxycline. Vertical mixing within the water column is inhibited by brackish surface waters originating from the Black Sea. Our sedimentary organic matter data (S1, S2, S3, TOC, HI and OI) reveals relatively higher and more biodegradable organic compounds in the Çinarcik Basin compared to the Central High. This is especially the case for HI and OI values, which are a typical mixture of Type II and Type III kerogen, related to marine phytoplankton and terrestrial higher-plant debris sources respectively (Tissot and Welte, 1984; Espitalié et al., 1985; Tolun et al., 2002). Strongly dysoxic conditions enhanced by gravity within the water column may enhance preservation of organic compounds exported to the seafloor (TOC $>2.8 \%$ in the $0-1 \mathrm{~cm}$ interval).

Prevailing dysoxia at our study sites $(<20 \mu \mathrm{mol} / \mathrm{L})$ restricts foraminiferal diversity to very low values ( $<<9, \mathrm{H}^{\prime}<0.97$ ). The only stress-tolerant species Bolivina vadescens, predominates living faunas at both Central High and south Çinarcik Basin. This taxon presented remarkably high standing stocks ( $>6500$ ind. $/ 100 \mathrm{~cm}^{2}$ ) in the microbial mat from Central High, potentially suggesting a symbiotic or trophic relationship with the prokaryote. It is well known that foraminifera, which present alternative metabolic pathways and ecological adaptation (e.g., denitrification ability, P-ER complexes, mutualism with prokaryotes), can thrive under extreme conditions prevailing in oxygendepleted environments (Sen Gupta and Machain-Castillo, 1993; Bernhard and Sen Gupta, 1999; Bernhard and Bowser, 1999; Bernhard, 2003; Risgaard-Petersen et al., 2006; Bernhard and Bowser, 2008; Høsglund et al., 2008; Piña-Ochoa et al., 2010; Koho et al., 2011; Bernhard et al., 2012a, b). Foraminifera living in methane- and sulfideenriched sediments from cold seep areas exhibit some of these metabolic adaptations (e.g., mutualism with prokaryotes) (e.g., Bernhard et al., 2001; Mackensen et al., 2006; Sen Gupta et al., 2007; Lobegeier and Sen Gupta, 2008) but may also rely on bacterial food (Panieri, 2006). At Central High, B. vadescens is an opportunistic taxon which may benefit from lack of competition for food in dysoxic and sulfidic sediments, proliferating in microbial mats by either feeding on bacterial biomass (and break-up products) or thriving in prokaryote symbiosis. Virgulinella fragilis, which is only found in the bacterial mat, was previously documented as a taxon able to retain multiple endosymbiotic bacteria and kleptoplasts in its cell (Bernhard, 2003; Tsuchiya et al., 2014). Endosymbionts may be both sulfide oxidisers and sulfate reducers (Bernhard, 2003; Tsuchiya, 2014). Globobulimina affinis and Chilostomella ovoidea are both large-sized foraminifera $(>125 \mu \mathrm{m})$ which occupy subsurface infaunal microhabitats and constitute substantial portions of living faunas. Their vertical distribution pattern has been documented in many OMZ and ventilated organic-matter-enriched ecosystems (e.g., Jannink et al., 1998; Kitazato et al., 2000; Fontanier et al., 2002, 2005, 2008a, 2013, 2014a, 2014b). Their abundance and microhabitat indicate enhanced bottom-water dysoxia, shallower oxygen penetration into the sediment and the availability of degraded organic matter below the sediment-water interface.

In the Early Holocene during sapropel formation in the Eastern Mediterranean, G. affinis was able to survive low oxygen conditions prevailing throughout the basin (Mullineaux and Lohmann, 1981). Accordingly, low-diversity fossil assemblages dominated by G. affinis (and Chilostomella spp.) were described during the S1 sapropelic event in the Aegean Sea, adjacent to the Sea of Marmara (e.g., Geraga et al., 2000; Kuhnt et al., 2007; Abu-Zied et al., 2008). To our knowledge, our data constitutes the first living evidence of this taxon dominating a lowdiversity fauna in an oxygen-depleted (and assumedly sapropel-like) 
environment. Globobulimina spp. possess alternative metabolic pathways (e.g... nitrate respiration; P-ER complex), enabling them to live in dysoxic to anoxic conditions (Risgaard-Petersen, 2006; Bernhard and Bowser, 2008; Piña-Ochoa et al., 2010; Koho et al., 2011).

Foraminiferal standing stocks and diversity recorded in the coarse sediment fraction of the south Çinarcik Basin are much lower than Central High despite sedimentary organic compounds (as a potential food source) being relatively more abundant below the sediment-water interface. A plausible explanation for this faunal depletion could be the absence of the large microbial mat either providing a food source or a filter capable of oxidizing poisonous hydrogen sulfide. Filamentous bacterial mats may provide refuges/oases for "extremophile" foraminifera in both dysoxic/anoxic and sulfidic ecosystems, and during sapropelic periods.

\subsection{Foraminiferal biogeochemistry}

$\mathrm{Mg} / \mathrm{Ca}$ and $\mathrm{Sr} / \mathrm{Ca}$ ratios in living Bolivina vadescens and Globobulimina affinis are similar at both study sites, which corresponds to the uniform temperature $\left(\sim 14.5^{\circ} \mathrm{C}\right)$ and salinity (38.7 psu) recorded in the deep waters of the Sea of Marmara (Table 1, Fig. 2). $\mathrm{Mg} / \mathrm{Ca}$ for living and fossil Globobulimina spp. has already been documented in other studies (Tachikawa et al., 2003; Skinner et al., 2003; Groenveld and Filippson, 2013; Weldeab et al., 2016). The Mg/Ca ratio in living individuals of $G$. affinis from the Bay of Biscay (NE Atlantic) clearly exhibit correlation with deep-water temperature variation (Tachikawa et al., 2003). However, our $\mathrm{Mg} / \mathrm{Ca}$ values for $G$. affinis (14-19 mmol/ mol) deviates from the ratio of $\sim 12 \mathrm{mmol} / \mathrm{mol}$ extrapolated with the paleothermometric calibration proposed by Skinner and Elderfield (2007) (i.e., $\mathrm{Mg} / \mathrm{Ca}=2.7 \times e^{(0.103 \times T)}$ ). Moreover, our $\mathrm{Mg} / \mathrm{Ca}$ values are higher than those of commonly used benthic genera like Cibicidoides, Uvigerina, Bulimina (Lear et al., 2002; Raitzsch et al., 2008; Huang et al., 2012), and also B. vadescens (our data).

The minor differences in the stable oxygen and carbon isotope signatures between both study sites are also of note. Following temperature-dependent fractionation and a uniform bottom water $\delta^{18} \mathrm{O}$ (i.e., $\delta^{18} \mathrm{O}_{\mathrm{BW}}=1.58 \%$; Table 1 ), the foraminiferal $\delta^{18} \mathrm{O}$ shows minor variability within each taxon from both environments $(2.01-1.90 \%$ for G. affinis; $1.44-1.68 \%$ for B. vadescens) (Table 3). The $\delta^{18} \mathrm{O}$ of $G$. affinis is relatively close to the equilibrium calcite $\delta^{18} \mathrm{O}$ of the bottom water $\left(\delta^{18} \mathrm{O}_{\text {e.c. }}=\sim 1.90 \%\right)$, with the $\Delta \delta^{18} \mathrm{O}$ values $\left(=\delta^{18} \mathrm{O}_{\text {G.affinis }}-\delta^{18} \mathrm{O}_{\text {e.c. }}\right)$ ranging between $+0.11 \%$ and $+0.0 \%$. Our results differ from the $\Delta \delta^{18} \mathrm{O}$ offset $(>+0.15 \%$ ) previously recorded by McCorkle et al. (1990) and Fontanier et al., (2006, 2008b) but are consistent with the minor offset $(+0.06 \%)$ recorded in the Western Mediterranean Sea by Schmiedl et al. (2004). The $\delta^{18} \mathrm{O}$ of $B$. vadescens is lighter than the $\delta^{18} \mathrm{O}_{\text {e.c }}$ of the bottom water, with the $\Delta \delta^{18} \mathrm{O}$ values ranging from $0.47 \%$ o to $-0.31 \%$. Such an overall depletion (compared to both the $\delta^{18} \mathrm{O}_{\text {e.c }}$, and G. affinis signatures) could be related to a growth-ratedependent fractionation, potentially related to the opportunistic behavior of $B$. vadescens.

The $\delta^{13} \mathrm{C}$ of $G$. affinis is lower than the calculated $\delta^{13} \mathrm{C}_{\text {DIC }}$ (depletion higher than $-1.35 \%$ at both study sites). Even though G. affinis occupies a subsurface microhabitat, its $\delta^{13} \mathrm{C}$ signature is heavier compared to the shallow infaunal B. vadescens, which ranges between $2.11 \%$ and $-2.34 \%$. Our observation does not comply with the "microhabitat" effect on carbon isotopes found by others (e.g. Schmiedl et al., 2004; Fontanier et al., 2006, 2008b, 2016) and again, this enhanced depletion of $B$. vadescens $\delta^{13} \mathrm{C}$ may result from its growth-rate fractionation. Alternatively, B. vadescens may reproduce and biomineralise its test when ephemeral fluid seeps through the sediment-water interface. In such a setting, this opportunistic taxon would record a depleted $\delta^{13} \mathrm{C}$ compared to Globobulimina spp. which have a lower metabolic rate (Nomaki et al., 2007). However, because intraspecific foraminiferal $\delta^{13} \mathrm{C}$ is relatively uniform between both study areas, it is unlikely that methane-derived carbon is being added to the pore waters in appreciable amounts at sampling. This supports the idea that both push cores dedicated to foraminiferal investigation were obtained either during episodes of reduced gas emission or were located outside the active methane emission zone. The presence of the bacterial mat (and its role either as food source or as hydrogen sulfide oxidizer) has a minor impact on the foraminiferal $\delta^{13} \mathrm{C}$ at Central High. We may have recorded an important depletion in foraminiferal $\delta^{13} \mathrm{C}$ if bacterial biomass constituted an important diet for both investigated species, but this was not the case in this study. An alternative explanation could be that internal controls in foraminiferal cells (e.g., pH-regulation, endosymbiotic activity) may temper the effect of pore water geochemistry and food assimilation on foraminiferal $\delta^{13} \mathrm{C}$ but this is based on only a few measurements and further investigations are necessary.

In recent work regarding modern fjords and OMZ, foraminiferal test $\mathrm{Mn} / \mathrm{Ca}$ has been proposed as a potentially reliable proxy of bottomwater oxygenation (Groenveld and Filippson, 2013; Koho et al., 2015). In the Sea of Marmara, the $\mathrm{Mn} / \mathrm{Ca}$ ratio is an order of magnitude higher for both tested living species from the south Çinarcik Basin compared to foraminifera from the bacterial mat at Central High. The foraminiferal test values follow trends recorded in pore water geochemistry. As assumed above, $\mathrm{Mn}$ (II) content in the Çinarcik basin may be related to alternate sources and inputs (i.e., Mn(IV)-enriched particles provided from the shelf by riverine inputs and by gravity-induced sedimentation). Therefore, $\mathrm{Mn} / \mathrm{Ca}$ enrichment for G. affinis and B. vadescens could be the result of physiographically-constrained accumulation/burial of manganese in the fully stratified Çinarcik Basin, where both strongly dysoxic conditions $(<10 \mu \mathrm{mol} / \mathrm{L})$ and enhanced deposition of organic matter occurs at the seafloor. In the deep Çinarcik Basin, our data shows that $\mathrm{Mn}$ (II) does not completely escape the seafloor in heavily reduced sediments and living foraminifera record this geochemical background with higher $\mathrm{Mn} / \mathrm{Ca}$ ratios. The interpretation of foraminiferal $\mathrm{Mn} / \mathrm{Ca}$ as a proxy for bottom water oxygenation is not straightforward and depends strongly on regional physiography, sedimentary diagenetic processes and water column structure.

\section{Conclusions}

In this preliminary study, we have investigated living foraminifera from the Sea of Marmara. We have focused on faunal composition and geochemical signatures (trace elements, oxygen and carbon stable isotopes) in foraminiferal tests at two sites (Central High and south Çınarcık Basin), located near previously documented cold seeps. Both study areas are characterized by a dysoxic water mass $\left(\mathrm{O}_{2}<20 \mu \mathrm{mol} /\right.$ L), and present extreme conditions characterized by remarkable spatial heterogeneity. Prevailing dysoxia at both study sites restricts foraminiferal diversity to very low values ( $\mathrm{S}<9, \mathrm{H}^{\prime}<0.97$ ). Stress-tolerant species Bolivina vadescens and Globobulimina affinis dominate living faunas in both environments, with higher standing stocks recorded at the shallower Central High site underneath a microbial mat. There is no obvious imprint of methane seepage in the geochemical signatures of benthic foraminifera collected at both sites. Our biogeochemical results suggest that interpreting bottom water oxygenation through foraminiferal $\mathrm{Mn} / \mathrm{Ca}$ ratios is neither straightforward nor reliable, and depends strongly on regional physiography, water column structure and sedimentary and diagenetic processes close to the seafloor.

\section{Acknowledgements}

We thank the captain and crew of the $R V$ Pourquoi pas? as well as the ROV Victor-6000 team for their technical support and advice. Financial support was provided by the European program "MARsite", under grant ENV.2012.6.4-2 - Long-term monitoring experiment in geologically active regions of Europe prone to natural hazards: The Supersite concept. We thank Pierre Henry (CEREGE), Dominique Birot (Ifremer) and Emeric Gautier (Ifremer) for their kind help concerning CTD 
measurements (MARNAUT cruise). We thank Florence LeCornec for her help with foraminiferal elemental concentration determination with the LA-ICPMS of the ALYSES Analytical Platform (Centre IRD France Nord). We thank Denis Fiorillo and Marie Balasse of the Museum of Natural History of Paris (MNHN) for allowing access to their machine, as well as their invaluable help while measuring bulk stable isotopes ( $\mathrm{C}$ and $\mathrm{O}$ ) of small quantities of benthic foraminifera carbonate. We have special thoughts for Pierre Anschutz (EPOC), who has provided valuable comments concerning Mn cycle. The ALYSES Analytical Platform IRD/ UPMC is supported by grants from Région Ile-de-France. Finally, we want to thank all reviewers (including associate editors) who provided very useful comments on this manuscript.

\section{Appendix A. Taxonomic list and plate references}

\begin{tabular}{lll}
\hline Taxon name & Reference & Plates \\
\hline Bolivina seminuda Cushman & Cushman (1911) & Pl. 34, Fig. 55 \\
Bolivina vadescens Cushman & Cushman (1933) & Pl. 8, Fig. 11 \\
Bulimina elegans d'Orbigny var. exilis Brady & Brady (1884) & Pl. 50, Figs. 5-6 \\
Chilostomella ovoidea Reuss & Reuss (1850) & Pl. 48, Fig. 12 \\
Fursenkoina schreibersiana (Czjzek) & Czjzek (1848) & Pl. 13, Fig. 18-21 \\
GloboBulimina affinis (d'Orbigny) & d'Orbigny et al. (1839) & Pl. 2, Fig. 23-26 \\
Gyroidina lamarckiana (d'Orbigny) & d'Orbigny et al. (1839) & Pl. 2, Fig. 13-15 \\
Leptohalysis scottii (Chaster) & Chaster (1892) & Pl. 1, Fig. 1 \\
Nonionella opima Cushman & Cushman (1947) & Pl. 20,Figs. 1-3 \\
Rectuvigerina phlegeri Berthois \& Le Calvez & Berthois and Le Calvez (1959) & Pl. 1, Fig. 11 \\
Virgulinella fragilis Grindell \& Collen & Grindell and Collen (1976) & Pl. 1,Figs. 1-8 \\
\hline
\end{tabular}

Appendix B. Benthic foraminiferal census data. Numbers are not standardized for sediment volume

\begin{tabular}{|c|c|c|c|c|c|c|c|}
\hline Depth interval $(\mathrm{cm})$ & $0-0.5$ & $0.5-1.0$ & $1.0-1.5$ & $1.5-2.0$ & $2.0-3.0$ & $3.0-4.0$ & $4.0-5.0$ \\
\hline \multicolumn{8}{|c|}{ MRS-DV01-PC-04 63-125 $\mu \mathrm{m}$} \\
\hline Bulimina elegans var. exilis & 18 & 5 & 1 & 1 & 1 & & \\
\hline Bolivina vadescens & 303 & 755 & 116 & 45 & 32 & 18 & 1 \\
\hline Bolivina seminuda & 4 & & & & & & \\
\hline Leptohalysis scottii & 7 & 1 & 1 & & & & \\
\hline Nonionella opima & 1 & & & & & & \\
\hline Rotaliidae & 1 & & & & & & \\
\hline Spiroplectammina sp. & 1 & & & & & & \\
\hline Virgulinella fragilis & 22 & 13 & & & & & \\
\hline Total Density & 357 & 774 & 118 & 46 & 33 & 18 & 1 \\
\hline Diversity & 7 & 4 & 3 & 2 & 2 & 1 & 1 \\
\hline \multicolumn{8}{|l|}{ MRS-DV01-PC-04 > $125 \mu \mathrm{m}$} \\
\hline Bolivina vadescens & 3 & 1 & 2 & & & & \\
\hline Bulimina elegans var. exilis & & & & & & 1 & \\
\hline Chilostomella ovoidea & & 2 & 3 & 1 & & & \\
\hline Fursenkoina schreibersiana & 1 & & & & & & \\
\hline Globobulimina affinis & 1 & 33 & 31 & 21 & 25 & 31 & 5 \\
\hline Gyroidina lamarckiana & & & 1 & & & & \\
\hline Nonionella opima & 2 & & & & & & \\
\hline Rectuvigerina phlegeri & 1 & 2 & 1 & & & & \\
\hline Virgulinella fragilis & 10 & 3 & 3 & & & & \\
\hline Total Density & 18 & 41 & 41 & 22 & 25 & 32 & 5 \\
\hline Diversity & 6 & 5 & 6 & 2 & 1 & 2 & 1 \\
\hline \multicolumn{8}{|c|}{ MRS-DV05-PC-06 63-125 $\mu \mathrm{m}$} \\
\hline Bolivina vadescens & 24 & 18 & 3 & & & & \\
\hline Nonionella opima & 1 & & & & & & \\
\hline Total Density & 25 & 18 & 3 & 0 & 0 & 0 & 0 \\
\hline Diversity & 2 & 1 & 1 & 0 & 0 & 0 & 0 \\
\hline \multicolumn{8}{|c|}{ MRS-DV05-PC-06 > $125 \mu \mathrm{m}$} \\
\hline Bolivina vadescens & 3 & & & & & & \\
\hline Chilostomella ovoidea & 1 & & & & & & \\
\hline GloboBulimina affinis & & 3 & 1 & & & & \\
\hline Total Density & 4 & 3 & 1 & 0 & 0 & 0 & 0 \\
\hline Diversity & 2 & 1 & 1 & 0 & 0 & 0 & 0 \\
\hline
\end{tabular}


Appendix C. Trace element data from foraminiferal tests. $\mathrm{Mg} / \mathrm{Ca}, \mathrm{Sr} / \mathrm{Ca}, \mathrm{Mn} / \mathrm{Ca}, \mathrm{Ba} / \mathrm{Ca}$ were measured on the last chamber (F) of size fraction-selected foraminifera from both sites. Due to chamber size limitation, only one measurement was taken per $\mathrm{F}$ chamber for Bolivina vadescens but two ablations were performed per Globobulimina affinis. Average values of these measurements are presented here

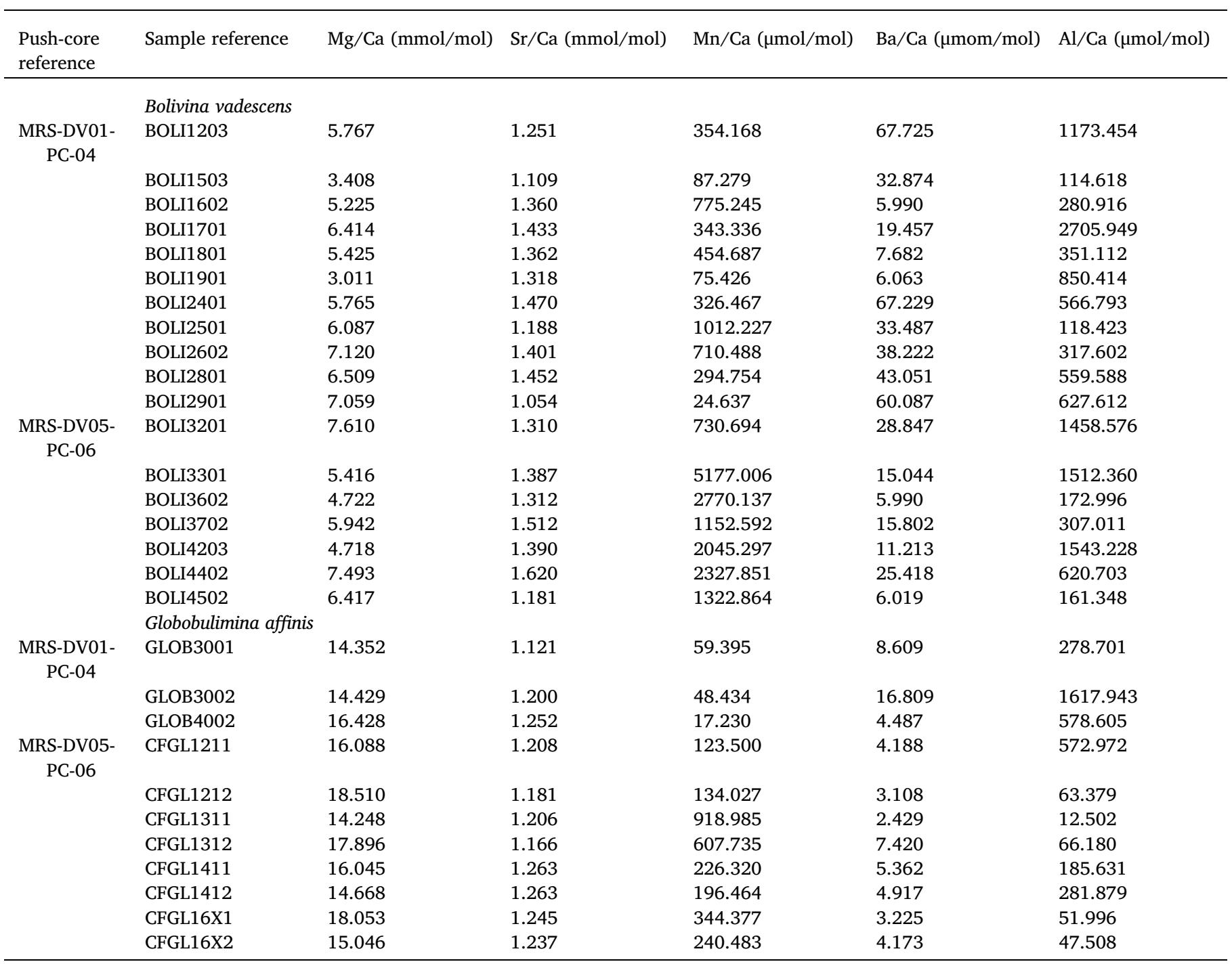

\section{Appendix D}

Previous paleo-ecological work has identified two different Brizalina species in fossil records from the Sea of Marmara (Kaminski et al., 2002). As pictured and described in the original publications by Seguenza (1862) and Williamson (1858), Brizalina catanensis (Seguenza) and Brizalina spathulata (Williamson) consist of an oblong- to triangle-shaped test with relatively sharp, smooth margins and an acuminate posterior extremity. In our samples, we did not find these species but rather recorded the dominance of Bolivina vadescens Cushman in living (stained) faunas. As originally described (Cushman, 1933), it consists of an elongate test with a rounded periphery. Early stage chambers rapidly increase in width after which the sides become nearly parallel (Fig. 4A-C). Sutures are distinct, limbate and particularly sigmoid. Aperture consists of a long, narrow loop-shaped opening.

Appendix E. Supplementary material

Supplementary data associated with this article can be found in the online version at http://dx.doi.org/10.1016/j.dsr2.2017.12.011.

\section{References}

Abu-Zied, R., Rohling, E.J., Jorissen, F.J., Fontanier, C., Casford, J.S.L., Cooke, S., 2008. Benthic foraminiferal response to changes in bottom water oxygenation and organic carbon flux in the eastern Mediterranean during LGM to recent times. Mar. Micropaleontol. 67, 46-68.

Akimoto, K., Tanaka, T., Hattori, M., Hotta, H., 1994. Recent benthic foraminiferal assemblages from the cold seep communities - a contribution to the methane gas indicator. In: Tsuchi, R. (Ed.), Pacific Neogene Events in Time and Space. University of Tokyo Press, Tokyo, pp. 11-25.

Alavi, S.N., 1988. Late Holocene Deep-Sea Benthic Foraminifera from the Sea of Marmara. Mar. Micropaleontol. 13, 213-237.

Anschutz, P., Sundby, B., Lefrançois, L., Luther III, G.W., Mucci, A., 2000. Interactions between metal oxides and species of nitrogen and iodine in bioturbated marine 
sediments. Geochim. Et. Cosmochim. Acta 64, 2751-2763.

Bastürk, O., Saydam, A.C., Saliboğlu, I., Yilmaz, A., 1986. Oceanography of the Turkish Straits (First Annual Report). 3 Chemical and Environmental Aspects. I.M.S. (M.E.T.U.) Rep. Istanbul Water SewerageAdm. (I.S.K.I.), Erdemli.

Baudin, F., Disnar, J.R., Aboussou, A., Savignac, F., 2015. Guidelines for Rock-Eval analysis of recent marine sediments. Org. Geochem. 86, 71-80.

Beck, C., Mercier de Lépinay, B., Schneider, J.-L., Cremer, M., Çağatay, N., Wendenbaum, E., Boutareaud, S., Ménot, G., Schmidt, S., Weber, O., Eris, K., Armijo, R., Meyer, B., Pondard, N., Gutscher, M.-A., MARMACORE Cruise Party, Turon, J.-L., Labeyrie, L., Cortijo, E., Gallet, Y., Bouquerel, H., Gorur, N., Gervais, A., Castera, M.-H., Londeix, L., de Rességuier, A., Jaouen, A., 2007. Late Qaternary co-seismic sedimentation in the Sea of Marmara's deep basins. Sediment. Geol. 199, 65-89.

Behar, F., Beaumont, V., de Penteado, B.H.L., 2001. Rock-Eval 6 technology: performances and developments. Oil Gas. Sci. Technol. Rev. IFP 56 (2), 111-134.

Bernhard, J.M., 2000. Distinguishing live from dead foraminifera: methods review and proper applications. Micropaleontology 46, 38-46.

Bernhard, J.M., 2003. Potential symbionts in bathyal foraminifera. Science 299, 861.

Bernhard, J.M., Sen Gupta, B.K., 1999. Foraminifera of oxygen-depleted environments. In: Sen Gupta, B.K. (Ed.), Modern Foraminifera. Kluwer Academic Publishers, Dordrecht, The Netherlands, pp. 200-216.

Bernhard, J.M., Bowser, S.S., 1999. Benthic Foraminifera of dysoxic sediments: chloroplast sequestration and functional morphology. Earth-Sci. Rev. 46, 149-165.

Bernhard, J.M., Bowser, S.S., 2008. Peroxisome proliferation in Foraminifera inhabiting the chemocline: an adaptation to reactive oxygen species exposure? J. Eukaryot. Microbiol. 55, 135-144.

Bernhard, J.M., Buck, K.R., Barry, J.P., 2001. Monterey Bay cold-seep biota: assemblages, abundance, and ultrastructure of living foraminifera. Deep-Sea Res. Part-I 48 , 2233-2249.

Bernhard, J.M., Casciotti, K.L., McIlvin, M.R., Beaudoin, D.J., Visscher, P.T., Edgcomb, V.P., 2012a. Potential importance of physiologically diverse benthic foraminifera in sedimentary nitrate storage and respiration. J. Geophys. Res. 117, G03002. http://dx. doi.org/10.1029/2012JG001949.

Bernhard, J.M., Edgcomb, V.P., Casciotti, K.L., McIlvin, M.R., Beaudoin, D.J., 2012b. Denitrification likely catalyzed by endobionts in an allogromiid foraminifer. ISME J. 6, 951-960.

Berthois, L., Le Calvez, Y., 1959. Deuxième Contribution à l'étude de la Sédimentation dans le golfe de Gascogne 23. pp. 323-377.

Beşiktepe, Ş., Sur, H.I., Özsoy, E., Latif, M.A., Oğuz, T., Ünlüata, Ü., 1994. The Circulation and Hydrography of the Marmara Sea. Prog. Oceanogr. 34, 285-334.

Boetius, A., Wenzhöfer, F., 2013. Seafloor oxygen consumption fuelled by methane from cold seeps. Nat. Geosci. 6, 725-734.

Boetius, A., Ravenschlag, K., Schubert, C.J., Rickert, D., Widdel, F., Gieseke, A., Amann, R., Jorgensen, B.B., Witte, U., Pfannkuche, O., 2000. A marine microbial consortium apparently mediating anaerobic oxidation of methane. Nature 407, 623-626.

Borowski, W.S., Paull, C.K., Ussler III, W., 1999. Global and local variations of interstitial sulphate gradients in deep-water, continental margin sediments: sensitivity to underlying methane and gas hydrates. Mar. Geol. 159, 131-154.

Bourry, C., Chazallon, B., Charlou, J.L., Donval, J.P., Ruffine, L., Henry, P., Géli, L., Çağatay, M.N., Inan, S., Moreau, M., 2009. Free gas and gas hydrates from the Sea of Marmara, Turkey Chemical and structural characterization. Chem. Geol. 264, $197-206$.

Brady, H.B., 1884. Report on the Foraminifera Dredged by H.M.S. Challenger, During the years 1873-1876. Rept. Challenger Expedition, London, England, Zool. 9. pp. 399.

Cağatay, M.N., 2003. Chronostratigraphy and sedimentology of the Marmara Sea over the last $40 \mathrm{ka}$. In: Proceedings of the European Geological Society, American Union of Geophysicists, European Union of Geophysicists General Assembly. Abstract, EAE03EAA-01883. EGS-AUG-EUG, Nice, France.

Cağatay, M.N., Görür, N., Algan, O., Eastoe, C., Tchapalyga, A., Ongan, D., Kuhn, T. Kuscu, I., 2000. Late Glacial-Holocene palaeoceanography of the Sea of Marmara: timing of connections with the Mediterranean and the Black Sea. Mar. Geol. 167, 191-206.

Cağatay, M.N., Özcan, M., Güngör, E., 2004. Pore-water and sediment geochemistry in the Marmara Sea (Turkey): early diagenesis and diffusive fluxes. Geochem.: Explor., Environ., Anal. 4, 213-225.

Campbell, K.A., 2006. Hydrocarbon seep and hydrothermal vent paleoenvironments and paleontology: past developments and future research directions. Palaeogeogr., Palaeoclimatol., Palaeoecol. 232, 362-407.

Carton, H., Singh, S.C., Hirn, A., Bazin, S., de Voogd, B., Vigner, A., Ricolleau, A., Cetin, S., Ocakoğlu, N., Karakoc, F., Sevilgen, V., 2007. Seismic imaging of the three dimensional architecture of the Cinarcik Basin along the North Anatolian Fault. J. Geophys. Res. 180. http://dx.doi.org/10.1029/2006JB004548 B06101.

Caulle, C., Koho, K.A., Mojtahid, M., Reichart, G.-J., Jorissen, F.J., 2014. Live (Rose Bengal stained) foraminiferal faunas from the northern Arabian Sea: faunal succession within and below the OMZ. Biogeosciences 11, 1155-1175.

Chaster, G.W., 1892. Report upon the foraminifera of the Southport Society of Natural Science District. Southport Soc. Nat. Sci., Rept., Southport, England, 1st Rept. (189091), Append., p. 57.

Chevalier, N., Bouloubassi, I., Brigel, D., Crémière, A., Taphanel, M.-H., Pierre, C., 2011. Authigenic carbonates at cold seeps in the Marmara Sea (Turkey): a lipid biomarker and stable carbon and oxygen isotope investigation. Mar. Geol. 288, 112-121.

Corliss, B.H., Emerson, S., 1990. Distribution of Rose Bengal stained deep-sea benthic foraminifera from the Nova Scotia continental margin and Gulf of Maine. Deep-Sea Res. Part-I 37, 381-400.

Crémière, A., Pierre, C., Blanc-Valleron, M.-M., Zitter, T., Çağatay, M.N., Henry, P., 2012. Methane-derived authigenic carbonates along the North Anatolian fault system in the Sea of Marmara (Turkey). Deep-Sea Res. Part-I 66, 114-130.
Cushman, J.A., 1911. A Monograph of the Foraminifera of the North Pacific Ocean; Part II Textulariidae. U.S. Nat. Mus., Bull., Washington, D. C., U.S.A, pp. 34.

Cushman, J. A., 1933. Some new Recent foraminifera from the Tropical Pacific. Contr. Cushman Lab. Foram. Res., Sharon, Mass., U.S.A., vol. 9, pt. 4, no. 137, p. 81.

Cushman, J.A., 1947. New Species and Varieties of Foraminifera off the Southeastern Coast of the United States 23. Cushman Lab. Foram. Res., Contr., Sharon, Mass, pp. 90.

Czjzek, J., 1848. Beitrag zur Kenntniss der fossilien Foraminiferen des Wiener Beckens 1. Naturw. Abh., Wien, Österreich, Bd. 2, pp. 147.

De Prunelé, A., 2015. Etude de la dynamique géochimique de deux zones à hydrates de gaz de la marge africaine (Ph.D. Thesis). Ifremer-UBO.

Dissard, D., Nehrke, G., Reichart, G.J., Nouet, J., Bijma, J., 2009. Effect of the fluorescent indicator calcein on $\mathrm{Mg}$ and $\mathrm{Sr}$ incorporation into foraminiferal calcite. Geochem. Geophys. Geosystems 10 (11). http://dx.doi.org/10.1029/2009GC002417.

Dissard, D., Nehrke, G., Reichart, G.J., Bijma, J., 2010a. The impact of salinity on the Mg/ $\mathrm{Ca}$ and $\mathrm{Sr} / \mathrm{Ca}$ ratio in the benthic foraminifera Ammonia tepida: results from culture experiments. Geochim. Cosmochim. Acta 74 (3), 928-940.

Dissard, D., Nehrke, G., Reichart, G.J., Bijma, J., 2010b. Impact of seawater pCO(2) on calcification and $\mathrm{Mg} / \mathrm{Ca}$ and $\mathrm{Sr} / \mathrm{Ca}$ ratios in benthic foraminifera calcite: results from culturing experiments with Ammonia tepida. Biogeosciences 7 (1). http://dx.doi.org/ 10.5194/bg-7-81-2010.

Ergin, M., 1994. Possible sources and pmechanisms of manganese enrichment in the deep sea sediments of the Marmara Trough depressions (NE-Mediterranean, Turkey) Oceanol. Acta 17, 535-546.

Espitalié, J., Deroo, G., Marquis, F., 1985. La pyrolyse Rock-Eval et ses applications. Partie I. Rev. De. l'Institut Fr. du Pétrole 40/5, 563-579.

Field, M.P., LaVigne, M., Murphy, K.R., Ruiz, G.M., Sherrell, R.M., 2007. J. Anal. At. Spectrom. 22, 1145-1151.

Fleischer, P., Orsi, T., Richardson, M., Anderson, A., 2001. Distribution of free gas in marine sediments: a global overview. Geo-Mar. Lett. 21, 103-122.

Fontanier, C., Jorissen, F.J., Licari, L., Alexandre, A., Anschutz, P., Carbonel, P., 2002 Live benthic foraminiferal faunas from the Bay of Biscay: faunal density, composition, and microhabitats. Deep-Sea Res. Part-I 49, 751-785.

Fontanier, C., Jorissen, F.J., Chaillou, G., Anschutz, P., Grémare, A., Griveaud, C., 2005 Live foraminiferal faunas from a $2800 \mathrm{~m}$ deep lower canyon station from the Bay of Biscay: faunal response to focusing of refractory organic matter. Deep-Sea Res. Part-I 52, 1189-1227.

Fontanier, C., Mackensen, A., Jorissen, F.J., Anschutz, P., Licari, L., Griveaud, C., 2006. Stable oxygen and carbon isotopes of live benthic foraminifera from the Bay of Biscay: microhabitats impact and seasonal variability. Mar. Micropaleontol. 58, 159-183.

Fontanier, C., Jorissen, F.J., Geslin, E., Zaragosi, S., Duchemin, G., Laversin, M., Gaultier, M., 2008a. Live and dead foraminiferal faunas from the Saint-Tropez Canyon (Bay of Fréjus): observations based on in situ and incubated cores. J. Foraminifer. Res. 38, 137-156.

Fontanier, C., Jorissen, F.J., Michel, E., Cortijo, E., Vidal, L., Anschutz, P., 2008b. Stable oxygen and carbon isotopes of live (stained) benthic foraminifera from Cap-Ferret Canyon (Bay of Biscay). J. Foraminifer. Res. 38, 39-51.

Fontanier, C., Metzger, E., Deflandre, B., Waelbroeck, C., Jouffreau, M., LeFloch, N. Jorissen, F.J., Etcheber, H., Bichon, S., Chabaud, G., Poirier, D., Grémare, A., 2013 Live (stained) benthic foraminifera off Walvis Bay (Namibia): a deep-sea ecosystem under the influence of benthic nepheloid layer. J. Foraminifer. Res. 43, 50-66.

Fontanier, C., Koho, K.A., Goñi-Urriza, M.S., Deflandre, B., Galaup, S., Ivanovsky, A., Gayet, N., Dennielou, B., Grémare, A., Bichon, S., Gassie, C., Anschutz, P., Duran, R., Reichart, G.J., 2014a. Benthic Foraminifera from the deep-water Niger delta (Gulf of Guinea): assessing present-day and past activity of hydrate pockmarks. Deep-Sea Res. Part-I 94, 87-106.

Fontanier, C., Duros, P., Toyofuku, T., Oguri, K., Koho, K.A., Buscail, R., Grémare, A., Radakovitch, O., Deflandre, B., De Nooijer, L.J., Bichon, S., Goubet, S., Ivanovsky, I., Chabaud, G., Menniti, C., Reichart, G.-J., Kitazato, H., 2014b. Living (stained) deepsea foraminifera off Hachinohe (NE Japan, Western Pacific): environmental interplay in oxygen-depleted ecosystems. J. Foraminifer. Res. 44, 281-299.

Fontanier, C., Sakai, S., Toyofuku, T., Garnier, E., Brandily, C., Eugene, T., Deflandre, B., 2016. Stable isotopes in deep-sea living (stained) foraminifera from the Mozambique Channel (eastern Africa): multispecies signatures and paleoenvironmental application. J. Oceanogr. http://dx.doi.org/10.1007/s10872-016-0401-1.

Foucher, J.P., Westbrook, G.K., Boetius, A., Ceramicola, S., Dupre, S., Mascle, J., Mienert, J., Pfannkuche, O., Pierre, C., Praeg, D., 2009. Structure and drivers of cold seep ecosystems. Oceanography 22 (1), 92-109.

Friedman, I., O’Neil, J.R., 1977. Compilation of stable isotope fractionations factors of geochemical interest (Geological Survey Professional Paper 440-KK). In: Fleischer, M. (Ed.), Data of Geochemistry, Sixth ed. U.S. Government Printing Office, Washington, DC, pp. 1-12.

Gaffey, S.J., Brönnimann, C.E., 1993. Effects of bleaching on organic and mineral phases in biogenic carbonates. J. Sediment. Petrol. 63, 752-754.

Gasperini, L., Polonia, A., Bortoluzzi, G., Henry, P., Le Pichon, X., Tryon, M., Çağatay, M.N., Géli, L., 2011. How far did the surface rupture of the 1999 Izmit earthquake reach in Sea of Marmara? Tectonics 30. http://dx.doi.org/10.1029/2010TC002726.

Géli, L, Henry, P., Zitter, T., Dupre, S., Tryon, M., Cağatay, M.N., de Lepinay, B.M., Le Pichon, X., Sengor, A.M.C., Gorur, N., Natalin, B., Ucarkus, G., Oezeren, S., Volker, D., Gasperini, L., Burnard, P., Bourlange, S., Marnaut Scientific, P., 2008. Gas emissions and active tectonics within the submerged section of the North Anatolian Fault zone in the Sea of Marmara. Earth Planet. Sci. Lett. 274, 34-39.

Geraga, M., Tsaila-Monopolis, S., Ioakim, C., Papatheodorou, G., Ferentinos, G., 2000. Evaluation of palaeoenvironmental changes during the last 18,000 years in the Myrtoon basin, SW Aegean Sea. Palaeoceanography, Palaeoclimatol. Palaeoecol. 156, 
$1-17$.

Glock, N., Schönfeld, J., Eisenhauer, A., Hensen, C., Mallon, J., Sommer, S., 2012. The role of benthic foraminifera in the benthic nitrogen cycle of the Peruvian oxygen minimum zone. Biogeosciences Discuss. 9, 17775-17817.

Gooday, A.J., 2003. Benthic Foraminifera (Protista) as tools in deep-water palaeoceanography: environmental influences on faunal characteristics. Adv. Mar. Biol. 46, $1-90$.

Gooday, A.J., Bernhard, J.M., Levin, L.A., Suhr, S.B., 2000. Foraminifera in the Arabian Sea oxygen minimum zone and other oxygen-deficient settings: taxonomic composition, diversity, and relation to metazoan faunas. Deep-Sea Res. Part-II 47, 24-54.

Grindell, D.S., Collen, J.D., 1976. Virgulinella fragilis n. sp. (Foraminiferida) from Wellington Harbour, New Zealand. Rev. Esp. Micro., Madr., Spain 8 (2), 274 (277, 278).

Groenveld, J., Filippson, H.L., 2013. Mg/Ca and Mn/Ca ratios in benthic foraminifera: the potential to reconstruct past variations in temperature and hypoxia in shelf regions. Biogeosciences 10, 5125-5138.

Halbach, P., Holzbecher, E., Reichel, T., Moche, R., 2004. Migration of the sulphatemethane reaction zone in marine sediments of the Sea of Marmara - can this mechanism be tectonically induced. Chem. Geol. 205.

Hayek, L.E.C., Buzas, M.A., 1997. Surveying Natural Populations. Columbia University Press, New York, pp. 563.

Heinz, P., Sommer, S., Pfannkuche, O., Hemleben, C., 2005. Living benthic foraminifera in sediments influenced by gas hydrates at the Cascadia convergent margin, NE Pacific. Mar. Ecol. Prog. Ser. 304, 77-89.

Herguera, J., Paull, C.K., Perez, E., Ussler, B., Peltzer, E., 2014. Limits to the sensitivity of living foraminifera to pore water carbon isotope anomalies in methane vent environments. Paleoceanography 29 (2014), 273-289.

Hill, T.M., Kennett, J.P., Valentine, D.L., 2004. Isotopic evidence for the incorporation of methane-derived carbon into foraminifera from modern methane seeps, Hydrate Ridge, Northeast Pacific. Geochim. Et. Cosmochim. Acta 68, 4419-4627.

Høsglund, S., Revsbech, N.P., Cedhagen, T., Nelsen, L.P., Gallardo, V.A., 2008. Denitrification, nitrate turn over, and aerobic respiration by benthic foraminiferans in the oxygen minimum zone off Chile. J. Exp. Mar. Biol. Ecol. 359, 85-91.

Huang, E., Mulitza, S., Paul, A., Groeneveld, J., Steinke, S., Schulz, M., 2012. Response of eastern tropical Atlantic central waters to Atlantic meridional overturning circulation changes during the Last Glacial Maximum and Heinrich Stadial 1. Paleoceanography 27 (PA3210). http://dx.doi.org/10.1029/2012PA002294,2012.

Jannink, N.T., Zachariasse, W.J., van der Zwaan, G.J., 1998. Living (Rose Bengal stained) benthic foraminifera from the Pakistan continental margin (northern Arabian Sea). Deep-Sea Res. Part-I 45, 1483-1513.

Jorissen, F.J., Fontanier, C., Thomas, E., 2007. Paleoceanographical proxies based on deep-sea benthic foraminiferal assemblage characteristics. In: Hillaire-Marcel, C., De Vernal, A. (Eds.), Paleoceanography of the Late Cenozoic 1 Methods in Late Cenozoic Paleoceanography: Elsevier, Amsterdam (875 pp).

Kaminski, M.A., Aksu, A., Box, M., Hiscott, R.N., Filipescu, S., Al-Salameen, M., 2002. Late Glacial to Holocene benthic foraminifera in the Marmara Sea: implications for Black Sea-Mediterranean Sea connections following the last deglaciation. Mar. Geol. 190, 165-202.

Karabulut, H., Bouin, M.P., Bouchon, M., Dietrich, M., Cornou, C., Aktar, M., 2002. The seismicity in the Eastern Marmara Sea after the 17 August 1999 Izmit earthquake. Bull. Seismol. Soc. Am. 92, 387-393.

Kirci-Elmas, E., Algan, O., Özkar-Öngen, I., Struck, U., Altenbach, A.V., Sagular, E.K., Nazik, A., 2008. Palaeoenvironmental Investigation of Sapropelic Sediments from the Marmara Sea: a biostratigraphic approach to palaeoceanographic history during the last Glacial-Holocene. Turk. J. Earth Sci. 17, 129-168.

Kitazato, H., 1996. Benthic foraminifera associated with cold seepages: discussion of their faunal characteristics and adaptations. Fossils 60, 48-52.

Kitazato, H., Shirayama, Y., Nakatsuka, T., Fujiwara, S., Shimanaga, M., Kato, Y., Okada, Y., Kanda, J., Yamaoka, A., Masukawa, T., Suzuki, K., 2000. Seasonal phytodetritus deposition and responses of bathyal benthic foraminiferal populations in Sagami Bay, Japan: preliminary results from "Project Sagami 1996-1999". Mar. Micropaleontol. 40, 135-149.

Koho, K.A., Piña-Ochoa, E., Geslin, E., Risgaard-Petersen, N., 2011. Vertical migration, nitrate uptake and denitrification: survival mechanisms of foraminifers (Globobulimina turgida) under low oxygen conditions. FEMS Microbiol. Ecol. 75, 273-283.

Koho, K.A., de Nooijer, L.J., Reichart, G.J., 2015. Combining benthic foraminiferal ecologyand shell $\mathrm{Mn} / \mathrm{Ca}$ to deconvolve past bottom water oxygenation and paleoproductivity. Geochim. Cosmochim. Acta 165, 294-306.

Kroopnick, P., 1985. The distribution of $\delta^{13} \mathrm{C}$ of $\Sigma \mathrm{CO} 2$ in the world oceans. Deep-Sea Res. $32,57-84$.

Kuhnt, T., Schmiedl, G., Ehrmann, W., Hamann, Y., Hemleben, C., 2007. Deep-Sea ecosystem variability of the Aegean Sea during the past $22 \mathrm{kyr}$ as revealed by Benthic Foraminifera. Mar. Micropaleontol. 64, 141-162.

Kurbjeweit, F., Schmiedl, G., Schiebel, R., Hemleben, C., Pfannkuche, O., Wallman, K., Schäfer, P., 2000. Distribution biomass and diversity of benthic foraminifera in relation to sediment geochemistry in the Arabian Sea. Deep-Sea Res. Part-II 47, 2913-2955.

Kuscu, I., Okamura, M., Matsuoka, H., Gokasan, E., Awata, Y., Tur, H., Simşek, M., 2005. Seafloor gas seeps and sediment failures triggered by the August 17, 1999 earthquake in the Eastern part of the Gulf of Izmit, Sea of Marmara, NW Turkey. Mar. Geol. 215, 193-214.

Lea, D.W., 1999. Trace elements in foraminiferal calcite. In: Sen Gupta, B.K. (Ed.) Modern Foraminifera. Kluwer Academic Publishers, Dordrecht, The Netherlands, pp. 259-277.

Lear, C.H., Rosenthal, Y., Slowey, N., 2002. Benthic foraminiferal Mg/Ca- paleothermometry: a revised core-top calibration. Geochim. Cosmochim. Acta 66, $3375-3387$.

Levin, L.A., Mendoza, G.F., 2007. Community structure and nutrition of deep methaneseep macrobenthos from the North Pacific (Aleutian) Margin and the Gulf of Mexico (Florida Escarpment). Mar. Ecol. 28, 131-151.

Lobegeier, M.K., Sen Gupta, B.K., 2008. Foraminifera of hydrocarbon seeps: gulf of Mexico. J. Foraminifer. Res. 38, 93-116.

Mackensen, A., Wollenburg, J., Licari, L., 2006. Low $\delta^{13} \mathrm{C}$ in tests of live epibenthic and endobenthic foraminifera at a site of active methane seepage. Paleoceanography 21. http://dx.doi.org/10.1029/2005PA001196.

Mallon, J., Glock, N., Schönfeld, J., 2012. The response of benthic foraminifera to lowoxygen conditions of the Peruvian oxygen minimum zone. In: Altenbach, A.V., Bernhard, J.M., Seckbach, J. (Eds.), ANOXIA: Evidence for Eukaryote Survival and Paleontological Strategies: Cellular Origin, Life in Extreme Habitats and Astrobiology 21 2. Springer, Dordrecht, The Netherlands, pp. 1305-1321.

McCorkle, D.C., Keigwin, L.D., Corliss, B.H., Emerson, S.R., 1990. The influence of microhabitats on the carbon isotopic composition of deep-sea benthic foraminifera. Paleoceanography 5, 161-185.

Mercier-de-Lepinay, B., Labeyrie, L., Çağatay, M.N., 2003. the MARMACORE team. Interplay between recent sedimentation and active tectonics in Marmara Sea. In: Proceedings of the European Geological Society-American Union of GeophysicistsEuropean Union of Geophysicists General Assembley. Abstract, EAE03-A-12694. EGS AUG-EUG, Nice, France.

Mouret, A., Anschutz, P., Lecroart, P., Chaillou, G., Hyacinthe, C., Deborde, J., Jorissen, F.J., Deflandre, B., Schmidt, S., Jouanneau, J.-M., 2008. Benthic geochemistry of managanese in the Bay of Biscay, and sediment mass accumulation rate. Geo-Mar. Lett. http://dx.doi.org/10.1007/s00367-008-0130-6.

Mullineaux, L.S., Lohmann, G.P., 1981. Quaternary stagnations and recirculation of the eastern Mediterranean: changes in the deep water recorded by fossil benthic foraminifera. J. Foraminifer. Res. 11, 20-39.

Munsel, D., Kramar, U., Dissard, D., Nehrke, G., Berner, Z., Bijma, J., Reichart, G.-J., Neumann, T., 2010. Heavy metal incorporation in foraminiferal calcite: results from multi-element enrichment culture experiments with Ammonia tepida. Biogeosciences 7, 2339-2350.

Murray, J.W., 2006. Ecology and Applications of Benthic Foraminifera. Cambridge University Press, Cambridge, pp. 426.

Murray, J.W., Bowser, S.S., 2000. Mortality, protoplasm decay rate, and reliability of staining techniques to recognize "living" foraminifera: a review. J. Foraminifer. Res. 30, 66-70.

Nomaki, H., Yamaoka, A., Shirayama, Y., Kitazato, H., 2007. Deep-sea benthic foraminiferal respiration rates measured under laboratory conditions. J. Foraminifer. Res. 37, 281-286. http://dx.doi.org/10.2113/gsjfr.37.4.281.

Nurnberg, D., Bijma, J., Hemleben, C., 1996. Assessing the reliability of magnesium in foraminiferal calcite as a proxy for water mass temperatures. Geochim. Cosmochim. Acta 60, 803-814.

Okay, A.I., Demirbag, E., Kurt, H., Okay, N., Kuşçu, I., 1999. An active, deep marine strike-slip basin along the North Anatolian fault in Turkey. Tectonics 18, 129-147.

O'Neil, J.R., Clayton, R.N., Mayeda, T.K., 1969. Oxygen isotope fractionation in divalent metal carbonates. J. Chem. Phys. 51, 5547-5558.

Orbigny, A. d.', 1839. Foraminifères des Iles Canaries. In: Barker-Webb, P., Berthelot, S (Eds.), Histoire Naturelle des Iles Canaries. Béthune, Paris, pp. 131.

Panieri, G., 2006. Foraminiferal response to an active methane seep environment: a case study from the Adriatic Sea. Mar. Micropaleontol. 61, 116-130.

Pearce, N.J.G., Perkins, W.T., Westgate, J.A., Gorton, M.P., Jackson, S.E., Neal, C.R., Chenery, S.P., 1997. A compilation of new and published major and trace elements data for NIST SRM 610 and NIST SRM 612 glass reference materials. Geostand. Geoanal.Res. 21, 115-144.

Piña-Ochoa, E., Koho, K.A., Geslin, E., Risgaard-Petersen, N., 2010. Survival and life strategy of the foraminiferan Globobulimina turgida through nitrate storage and denitrification. Mar. Ecol. Progress. Ser. 417, 39-49.

Prinzhofer, A., Deville, E., 2013. Origins of hydrocarbon gas seeping out from offshore mud volcanoes in the Nile delta. Tectonophysics 591, 52-61.

Raitzsch, M., Kuhnert, H., Groeneveld, J., Bickert, T., 2008. Benthic foraminifer $\mathrm{Mg} / \mathrm{Ca}$ anomalies in South Atlantic core top sediments and their implications for paleothermometry. Geochem. Geophys. Geosyst. 9, Q05010. http://dx.doi.org/10. 1029/2007GC001788.

Rank, D., Ôzsoy, E., Salihoğlu, İ., 1999. Oxygen-18, deuterium and tritium in the Black Sea and the Sea of Marmara. J. Environ. Radioact. 43, 231-245.

Rathburn, A.E., Levin, L.A., Held, Z., Lohmann, K.C., 2000. Benthic foraminifera associated with cold methane seeps on the northern California margin: ecology and stable isotopic composition. Mar. Micropaleontol. 38, 247-266.

Rathburn, A.E., Pérez, M.E., Martin, J.B., Day, S.A., Mahn, C., Gieskes, J., Ziebis, W., Williams, D., Bahls, A., 2003. Relationships between the distribution and stable isotopic composition of living benthic foraminifera and cold methane seep biogeochemistry in Monterey Bay, California. Geochem. Geophys., Geosyst. http://dx. doi.org/10.1029/2003GC000595.

Reuss, A. E., 1850. Neue Foraminiferen aus den Schichten des Österreichischen Tertiärbeckens. K. Akad. Wiss. Wien, Math.-Nat. Cl., Denkschr., Wien, Österreich, Bd. 1, p. 380.

Risgaard-Petersen, N., Langezaal, A., Ingvardsen, S., Schmid, M.C., Jetten, M.S.M., Op den Camp, H.J.M., Derksen, J.W.M., Piña-Ochoa, E., Eriksson, S.P., Nielsen, S.P., Revsbech, N.P., Cedhagen, T., van der Zwaan, G.J., 2006. Evidence for complete denitrification in a benthic foraminifer. Nature 443, 93-96.

Ritt, B., Sarrazin, J., Caprais, J.-C., Noël, P., Gauthier, O., Pierre, C., Henry, P., Desbruyères, D., 2010. First insights into the structure and environmental setting of cold-seep communities in the Marmara Sea. Deep-Sea Res. Part-I 57, 1120-1136. 
Ruffine, L., Germain, Y., Polonia, A., de Prunelé, A., Croguennec, C., Donval, J.P., PitelRoudaut, M., 2015. Pore water geochemistry at two seismogenic areas in the sea of Marmara. Geochem. Geophys. Geosyst. 16 (7), 2038-2057.

Sahling, H., Rickert, D., Linke, P., Suess, E., Lee, R.W., 2002. Community structure at gas hydrate deposits at the Cascadia convergent margin, NE Pacific. Mar. Ecol. Prog. Ser. 231, 121-138.

Schmiedl, G., Pfeilsticker, M., Hemleben, C., Mackensen, A., 2004. Environmental and biological effects on the stable isotope composition of Recent deep-sea benthic foraminifera from the Mediterranean Sea. Mar. Micropaleontol. 51, 29-152.

Schumacher, S., Jorissen, F.J., Dissard, D., Larkin, K.E., Gooday, A.J., 2007. Live (Rose Bengal stained) and dead benthic foraminifera from the oxygen minimum zone of the Pakistan continental margin (Arabian Sea). Mar. Micropaleontol. 62, 45-73.

Seeberg-Elverfeldt, J., Schlüter, M., Feseker, T., Kölling, M., 2005. Rhizon sampling of pore waters near the sediment/water interface of aquatic systems. Limnol. Oceanogr.: Methods 3, 361-371.

Seguenza, G., 1862. Prime ricerche intorno ai rizopodi fossili delle argille Pleistoceniche dei dintorni di Catania. Annad. Gioenia Sci. Nat. Catania, Atti, Catania, Italia, ser. 2, tomo 18, pp. 113, 25.

Sen Gupta, B.K., Machain-Castillo, M.L., 1993. Benthic foraminifera in oxygen-poor habitats. Mar. Micropaleontol. 20, 183-202.

Sen Gupta, B.K., Aharon, P., 1994. Benthic foraminifera of bathyal hydrocarbon vents of the Gulf of Mexico: initial report on communities and stable isotopes. Geo-Mar. Lett. 14, 88-96.

Sen Gupta, B.K., Platon, E., Bernhard, J.M., Aharon, P., 1997. Foraminiferal colonization of hydrocarbon-seep bacterial mats and underlying sediment, Gulf of Mexico slope. J. Foraminifer. Res. 27, 292-300.

Sen Gupta, G.K., Smith, L.E., Lobegeier, M.K., 2007. Attachment of foraminifera to vestimentiferan tubeworms at cold seeps: refuge from seafloor hypoxia and sulfide toxicity. Mar. Micro. 62, 1-6.

Skinner, L.C., Elderfield, H., 2007. Rapid fluctuations in the deep North Atlantic heat budget during the last glacial period. Paleoceanography 22, PA1205. http://dx.doi org/10.1029/2006PA001338.

Skinner, L.C., Shackleton, N.J., Elderfield, H., 2003. Millennial-scale variability of deepwater temperature and $\delta^{18} \mathrm{O}_{\mathrm{dw}}$ indicating deep-water source variations in the Northeast Atlantic, 0-34 cal. ka BP. Geochem. Geophys. Geosyst. 4 (12), 1098. http://dx.doi.org/10.1029/2003GC000585.

Sibuet, M., Olu, K., 1998. Biogeography, biodiversity and fluid dependence of deep-sea cold-seep communities at active and passive margins. Deep-Sea Res. 45, 517-567.

Sills, G.C., Wheeler, S., 1992. The significance of gas for offshore operations. Cont. Shelf Res. 12, 1239-1250.
Spencer, D.W., Brewer, P.G., 1971. Vertical advection diffusion and redox potentials as controls on the distribution of manganese and other trace metals dissolved $\mathrm{m}$ waters of the Black Sea. J. Geophys. Res. 76, 5877-5892.

Tachikawa, K., Fontanier, C., Jorissen, F.J., Bard, E., 2003. Mg/Ca and Sr/Ca in living benthic foraminiferal tests from the northeastern Atlantic. Abstract EGU meeting, Nice, France.

Tissot, B.P., Welte, D.H., 1984. Petroleum Formation and Occurrence. Springer, Berlin, pp. 699.

Tolun, L., Cağatay, M.N., Carrigan, W.J., 2002. Organic Geochemistry and origin of late glacial-holocene sapropelic layers and associated sediments in Marmara Sea. Mar. Geol. 190, 163-174.

Torres, M.E., Mix, A.C., Kinports, K., Haley, B., Klinkhammer, G.P., McManus, J., de Angelis, M.A., 2003. Is methane venting at the seafloor recorded by $\delta^{13} \mathrm{C}$ of benthic foraminifera shells? Paleoceanography 18. http://dx.doi.org/10.1029/ 2002PA000824.

Tsuchiya, M., Toyofuku, T., Umetsu, K., Brüchert, V., Collen, J., Yamamoto, H., Kitazato, H., 2014. Cytologic and genetic characteristics of endobiotic bacteria and kleptoplasts of Virgulinella fragilis (Foraminifera). J. Eukaryot. Microbiol. ISSN 1066-5234 (0), 1-16.

Ünlüata, Û., Özsoy, E., 1986. Oceanography of the Turkish Straits (First Annual Report). Vol. 2: Oxygen Deficiency of the Sea of Marmara. I.M.S. (M.E.T.U.) Rep. Istanbul Water Sewerage Adm. (I.S.K.I.), Erdemli.

Walton, W.R., 1952. Techniques for recognition of living Foraminifera. Contrib. Cushman Found. Foraminifer. Res. 3, 56-60.

Weldeab, S., Arce, A., Kasten, S., 2016. Mg/Ca- $\Delta \mathrm{CO}_{3}^{2-}$ pore water - temperature calibration for Globobulimina spp.: a sensitive paleothermometer for deep-sea temperature reconstruction. Earth Planet. Sci. Lett. 438, 95-102.

Williamson, W.C., 1858. On the Recent foraminifera of Great Britain. Ray Soc., Lond., Engl. 1858, 76.

Wollenburg, J.E., Raitzsch, M., Tiedemann, R., 2015. Novel high-pressure culture experiments on deep-sea benthic foraminifera - evidence for methane seepage-related $\delta^{13} \mathrm{C}$ of Cibicides wuellerstorfi. Mar. Micropaleontol. 117, 47-64.

Woulds, C., Cowie, G.L., Levin, L.A., Andersson, J.H., Middelburg, J.J., Vandewiele, S., Lamont, P.A., Larkin, K.E., Gooday, A.J., Schumacher, S., Whitcraft, C., Jeffreys, R.M., Schwartz, M., 2007. Oxygen as a control on seafloor biological communities and their roles in sedimentary carbon cycling. Limnol. Oceanogr. 52, 1698-1709.

Zitter, T.A.C., Henry, P., Aloisi, G., Delaygue, G., Cağatay, M.N., de Lepinay, B.M., AlSamir, M., Fornacciari, F., Tesmer, M., Pekdeger, A., Wallmann, K., Lericolais, G., 2008. Cold seeps along the main Marmara fault in the Sea of Marmara (Turkey). Deep-Sea Res. Part-I 55, 552-570. 